\title{
The past ecology of Abies alba provides new perspectives on future responses of silver fir forests to global warming
}

\author{
Willy Tinner, ${ }^{1,2,3,11}$ Daniele Colombaroli, ${ }^{1,2}$ Oliver Heiri, ${ }^{1,2}$ Paul D. Henne, ${ }^{1,2,3}$ Marco Steinacher, ${ }^{2,4}$ \\ Johanna Untenecker, ${ }^{5}$ Elisa Vescovi, ${ }^{1,2}$ Judy R. M. Allen, ${ }^{6}$ Gabriele Carraro, ${ }^{7}$ Marco Conedera, ${ }^{8}$ \\ Fortunat Joos, ${ }^{2,4}$ André F. Lotter, ${ }^{9}$ Jürg Luterbacher, ${ }^{5}$ Stéphanie Samartin, ${ }^{1,2}$ and Verushka Valsecchi ${ }^{10}$ \\ ${ }^{1}$ Paleoecology, Institute of Plant Sciences, University of Bern, Altenbergrain 21, CH-3013 Bern, Switzerland \\ ${ }^{2}$ Oeschger Centre for Climate Change Research, University of Bern, Zachringerstrasse 25, CH-3012 Bern, Switzerland \\ ${ }^{3}$ Forest Ecology, Institute of Terrestrial Ecosystems, ETH Zurich, Universitätstrasse 16, CH-8092 Zurich, Switzerland \\ ${ }^{4}$ Climate and Environmental Physics, Physics Institute, University of Bern, Sidlerstrasse 5, CH-3012 Bern, Switzerland \\ ${ }^{5}$ Climatology, Climate Dynamics and Climate Change, Department of Geography, Justus Liebig University of Giessen, \\ Senckenbergstrasse 1, D-35390 Giessen, Germany \\ ${ }^{6}$ School of Biological and Biomedical Sciences, Durham University, South Road, Durham DH1 3LE United Kingdom \\ ${ }^{7}$ Dionea SA, Environmental Consulting, CH-6600 Locarno, Switzerland \\ ${ }^{8}$ Insubric Ecosystems, Swiss Federal Institute for Forest, Snow and Landscape Research WSL, via Belsoggiorno 22, \\ CH-6500 Bellinzona, Switzerland \\ ${ }^{9}$ Paleoecology, Department of Physical Geography, Utrecht University, Budapestlaan 4, NL-3584 CD Utrecht, The Netherlands \\ ${ }^{10}$ Institute of Evolution Sciences, CNRS, Place Eugène Bataillon, F-34090 Montpellier, France
}

Abstract. Paleoecology can provide valuable insights into the ecology of species that complement observation and experiment-based assessments of climate impact dynamics. New paleoecological records (e.g., pollen, macrofossils) from the Italian Peninsula suggest a much wider climatic niche of the important European tree species Abies alba (silver fir) than observed in its present spatial range. To explore this discrepancy between current and past distribution of the species, we analyzed climatic data (temperature, precipitation, frost, humidity, sunshine) and vegetation-independent paleoclimatic reconstructions (e.g., lake levels, chironomids) and use global coupled carbon-cycle climate (NCAR CSM1.4) and dynamic vegetation (LandClim) modeling. The combined evidence suggests that during the mid-Holocene $(\sim 6000$ years ago), prior to humanization of vegetation, A. alba formed forests under conditions that exceeded the modern (1961-1990) upper temperature limit of the species by $\sim 5-7^{\circ} \mathrm{C}$ (July means). Annual precipitation during this natural period was comparable to today $(>700-800 \mathrm{~mm})$, with drier summers and wetter winters. In the meso-Mediterranean to sub-Mediterranean forests $A$. alba co-occurred with thermophilous taxa such as Quercus ilex, Q. pubescens, Olea europaea, Phillyrea, Arbutus, Cistus, Tilia, Ulmus, Acer, Hedera helix, Ilex aquifolium, Taxus, and Vitis. Results from the last interglacial (ca. 130 000-115000 BP), when human impact was negligible, corroborate the Holocene evidence. Thermophilous Mediterranean A. alba stands became extinct during the last 5000 years when land-use pressure and specifically excessive anthropogenic fire and browsing disturbance increased. Our results imply that the ecology of this key European tree species is not yet well understood. On the basis of the reconstructed realized climatic niche of the species, we anticipate that the future geographic range of $A$. alba may not contract regardless of migration success, even if climate should become significantly warmer than today with summer temperatures increasing by up to $5-7^{\circ} \mathrm{C}$, as long as precipitation does not fall below $700-800 \mathrm{~mm} / \mathrm{yr}$, and anthropogenic disturbance (e.g., fire, browsing) does not become excessive. Our finding contradicts recent studies that projected range contractions under global-warming scenarios, but did not factor how millennia of human impacts reduced the realized climatic niche of $A$. alba.

Key words: Abies alba; bioclimatic envelope models; climate models; climatic niche; dynamic vegetation models; global change; paleoclimatology; paleoecology; realized niche.

\section{INTRODUCTION}

Manuscript received 21 December 2012; revised 15 March 2013; accepted 18 March 2013. Corresponding Editor: A. W. D'Amato.

${ }^{11}$ E-mail: willy.tinner@ips.unibe.ch
Paleoecology can provide essential insights about the long-term impacts of changing climate, disturbance, and land-use regimes on species and ecosystems. 
For example, consideration of paleoecological records allowed the reclassification of presumed invasive exotics as native species (e.g., van Leeuwen et al. 2008), the identification of natural vegetation composition in strongly humanized landscapes (e.g., Tinner et al. 1999) and the documentation of natural fire regimes (e.g., Whitlock et al. 2003) as a baseline for nature conservation, restoration, and management (Willis and Birks 2006, Jackson and Hobbs 2009). In this role of establishing natural baselines, paleoecology serves as a complement to observations and experiments in ecology as paleoclimatology (e.g., Arctic and Antarctic ice core analyses) does for climatology (Blunier and Brook 2001). In particular, it delivers long-term variability data as an empirical base for understanding ecological extremes, shifts, complex feedbacks, and tipping points (Overpeck et al. 2003). In recent efforts, paleoenvironmental time series contributed to a better understanding of key ecosystem components such as biodiversity (Willis et al. 2007), atmospheric composition and dynamics (Raynaud et al. 2003), carbon cycling (Pedersen et al. 2003, Bozbiyik et al. 2011), ocean circulation (Alley et al. 2003), fire (Power et al. 2008), and land use (Büntgen et al. 2011) by providing valuable information about their long-term functioning, resilience, and vulnerability. In this study we used the European key species Abies alba Mill. (silver fir tree) to illustrate how interdisciplinary paleo-environmental research can contribute to a better understanding of the ecology and more specifically the climatic niche of species.

Abies alba (silver fir; see Plate 1) is the tallest tree species of Europe, reaching heights in excess of $60 \mathrm{~m}$, where sufficient moisture is available (Mayer 1984a, $b$, Lauber and Wagner 1996, Ellenberg 2009, Ellenberg and Leuschner 2010). The species plays a prominent role in many European forest types and produces precious timber that is used in construction and furniture. In mountainous areas such as the Alps, it forms important protective forests for infrastructure such as settlements, roads, and railways. It is commonly assumed on the basis of the modern distribution that $A$. alba prefers cool and rather moist habitats (e.g., Pignatti 1997, 2005, Ellenberg 2009). However, new paleoecological observations from central and southern Europe show Holocene and Interglacial ranges that do not match the current A. alba distribution (e.g., Tinner et al. 1999, Allen et al. 2002, Wick et al. 2003, Colombaroli et al. 2007, Bellini et al. 2009, Vescovi et al. 2010a, b). For example, before intense land use began and anthropogenic fire activity started to increase $\sim 5000$ years ago, $A$. alba formed forests under warm-temperate to subtropical conditions in southern Europe, where modern mean July temperatures span from $21^{\circ} \mathrm{C}$ to $25^{\circ} \mathrm{C}$ and the species is presently very rare or even entirely absent. A similar picture with occurrences of Abies alba under significantly warmer-than-present conditions emerges from the last Interglacial $(\sim 120000$ years ago; Lang 1994, Allen and Huntley 2009), when A. alba occupied a wider range of habitats and human impact was negligible. Today, disturbance-adapted European deciduous oaks (e.g., Quercus pubescens, Q. petraea), sweet chestnut (Castanea sativa), and evergreen oaks (e.g., Quercus ilex) dominate thermophilous forest communities in the areas where $A$. alba disappeared during the mid and late Holocene.

Recent correlative bioclimatic and dynamic vegetation modeling studies support the hypothesis of a wider potential range of $A$. alba (Keller et al. 2002, Svenning and Skov 2004, Henne et al. 2013). However, humanization of vegetation since the onset of farming (Neolithic, ca. 7500-4200 cal. BP in the study area) markedly influenced the dimensions, structure, and species composition of European forests (Pyne 1997). Mesophilous, late-successional, shade-tolerant, slowgrowing, and fire-sensitive trees such as Abies alba were particularly affected by human pressure (Pignatti 1997, Ellenberg and Leuschner 2010). This makes it difficult to estimate the natural potential range of such species in Europe on the basis of ecological observations (e.g., relevés, vegetation surveys). The significant mismatch between the past ( $>5000$ years ago) and present spatial ranges suggests that the ecology and especially the climatic niche of this key European species (including several ecotypes or varieties; Pignatti 1982) are currently not well understood. This incertitude makes assessments about the potential responses of $A$. alba and other latesuccessional species to future climate change (IPCC 2007) speculative. Filling this knowledge gap may improve mitigation strategies, as, for instance, promoting $A$. alba may help maintain natural central and southern European forest ecosystems under globalwarming scenarios. Likewise, A. alba may provide the best potential for maintaining high productivity (timber production reaching $26 \mathrm{~m}^{3} \cdot \mathrm{yr}^{-1} \cdot \mathrm{ha}^{-1}$; Badoux 1983) and protecting carbon stocks in forests under a warming climate (up to $1300 \mathrm{~m}^{3}$ of wood/ha in silver fir forests; Schütt et al. 2004).

To assess the existing uncertainties about the ecology of silver fir forests, we quantitatively compared extinct and persisting $A$. alba communities (as inferred from paleobotanical analyses) across a wide spatiotemporal range that spans from central to southern Europe and covers selected periods of the past 130000 years. We investigated the climatic niche by comparing current and past climatic conditions in the realized spatial range and the regions of fossil $A$. alba evidence. Current climatic conditions were explored by using seven climatic parameters (comprising 86 climatic variables), past climatic conditions were explored by consulting available non-botanical paleoclimatic reconstructions and models. Dynamic vegetation modeling approaches were used to verify whether the species would be able to grow under current and past Mediterranean climatic conditions in absence of human impact. We addressed the implications of our results for the future of European forests under changing climatic conditions. 


\section{Methods \\ Study object and area}

The genus Abies includes 50 species of which nine are exclusively present in the Mediterranean realm (Bernetti 1995). Abies alba is a mesophilous, late-successional, south-central European tree species (Pignatti 1997, Ellenberg 2009). Since it is the tallest tree of Europe ( $>60 \mathrm{~m}$ height), long living ( $>500$ years), very shade tolerant, and forms a dense canopy (Lauber and Wagner 1996, Ellenberg and Leuschner 2010), it can easily overtop and dominate other tall tree species where environmental conditions are favorable for its growth. Autoinhibition, for instance, by aqueous extracts of needle leachates on seedling germination and root growth (Becker and Drapier 1984, 1985), regeneration in small patches, and rapidly decaying litter allow the consociation of $A$. alba with many other arboreal species (Bernetti 1995). Thus $A$. alba is considered an important ecological and functional balancer of European forests (Ott et al. 1997) and can serve as a keystone species (Simberloff 1998) for maintaining high biodiversity in forested ecosystems.

If compared with other European and Mediterranean Abies species, silver fir is considered to prefer the coolest and moistest sites (Mayer 1984b), inhabiting areas with summer temperatures between approximately $14^{\circ} \mathrm{C}$ and $19^{\circ} \mathrm{C}$, whereas more thermophilous firs (e.g., A. cilicica, A. numidica, A. marocana, A. cephalonica) may form forests at summer temperatures of $\sim 19-23^{\circ} \mathrm{C}$ (Mayer 1984b). A. alba is particularly sensitive to ungulate browsing (it is a very palatable food source in winter) and fire (Tinner et al. 2000, Schütt et al. 2004). Insects, fungi, late frost, frost desiccation, and industrial emissions (especially $\mathrm{SO}_{2}$ ) may also affect the tree (Lingg 1986, Schütt et al. 2004, Ellenberg 2009, Kozakova et al. 2011). The seed dispersal of $A$. alba is efficient and comparable to that of other wind-dispersed trees (e.g., Picea abies; Sagnard et al. 2007, Szymura et al. 2007, Cremer et al. 2012). Taproots allow the species to grow on dry locations, for instance, in the Mediterranean region, because they can reach deep-water reserves that accumulate during the wet winter period (Aussenac 2002). On the other hand, limited stomatal control makes the species susceptible to low air humidity and low spring precipitation (Ducrey 1999). If compared to other Mediterranean Abies species, A. alba can grow under more arid conditions than $A$. numidica, $A$. nebrodensis, and $A$. pinsapo, equals $A$. bornmulleriana, A. equi-trojani, A. marocana, and $A$. borisii-regis, but is outpaced by $A$. cephalonica, A. cilicica, and A. nordmanniana (Aussenac 2002).

A. alba survived the last ice-age in close proximity to the Alps (Willis and McElwain 2002, Kaltenrieder et al. 2009). The range expanded from southern to central Europe during the Holocene after climatic conditions became suitable (Tinner and Lotter 2001, 2006). Prior to 8200 cal yr BP, climatic conditions in central Europe were probably too continental, with hot dry summers and cold, frost-prone winters and springs, to allow the species to dominate or co-dominate in the vegetation (Tinner and Lotter 2001, 2006).

We selected 12 sites over a wide climatic gradient in Switzerland and Italy (Figs. 1 and 2, Table 1) where $A$. alba was dominant under natural or quasi-natural conditions during the early and/or mid-Holocene. These sites have been investigated during the past 15 years with modern palynological approaches, assuring highest taxonomic resolution. Furthermore, they are representative of both the extinct and remaining $A$. alba forests in Europe. One site (Lago Grande di Monticchio; Allen and Huntley 2009) also covers the last interglacial (Eemian, ca. 130 000-115000 BP). At four of our study sites, A. alba still forms pure or mixed forests with Fagus sylvatica (Soppensee, Foppe, Piano, Greppo), whereas at Saegistalsee, Starlarescio, Origlio, Muzzano, Pavullo, Massaciuccoli, Accesa, and Monticchio, A. alba forests disappeared during the mid or late Holocene (Fig. 1). The modern vegetation at the sites that lost $A$. alba consists of meadows and open Picea abies stands at Saegistalsee, open stands of Larix with Rhododendron at Starlarescio, deciduous Castanea sativa-Quercus forests at Origlio, Muzzano, and Pavullo, and deciduous and evergreen Quercus forests or maquis at Massaciuccoli, Accesa, and Monticchio. Most of the study sites with relict $A$. alba are intensively used for arable or pastoral agriculture and the remaining forests are thus highly fragmented (e.g., Soppensee, Foppe).

The climate at the study sites ranges from cold subalpine (or boreal) to warm Mediterranean (or subtropical). Extinct populations were located at the coldest and warmest edges of the former $A$. alba range, where today's July temperatures reach $9-12^{\circ} \mathrm{C}$ and $21-$ $25^{\circ} \mathrm{C}$, respectively (Fig. 2). Annual precipitation varies significantly among the sites, from $\sim 700$ to $2500 \mathrm{~mm}$. Generally, the warmest sites are the driest (Fig. 2), with remarkable exceptions in the Insubrian region in northern Italy and southern Switzerland, where mean July temperatures reach $21-23^{\circ} \mathrm{C}$, and mean annual precipitation exceeds $1500 \mathrm{~mm}$ and falls mainly during the vegetation period (e.g., Origlio and Muzzano).

\section{Paleoecological data and data analysis}

Pollen samples were prepared according to standard methods (e.g., Moore et al. 1991). Further details are provided in the original literature (see Table 1). Unpublished data follow the preparation methods listed in Tinner et al. (1999). Palynological identification was done with light microscopy at 400-1000× magnification. We selected representative pollen assemblages (about five samples per site; see Table 2) from periods before or at the onset of noticeable human impact (Eemian, early or mid-Holocene). Additional samples were selected from the top sediments, which reflect modern or historical conditions. Only sites reaching a minimum of $5 \%$ of Abies pollen at any time in the Holocene or 


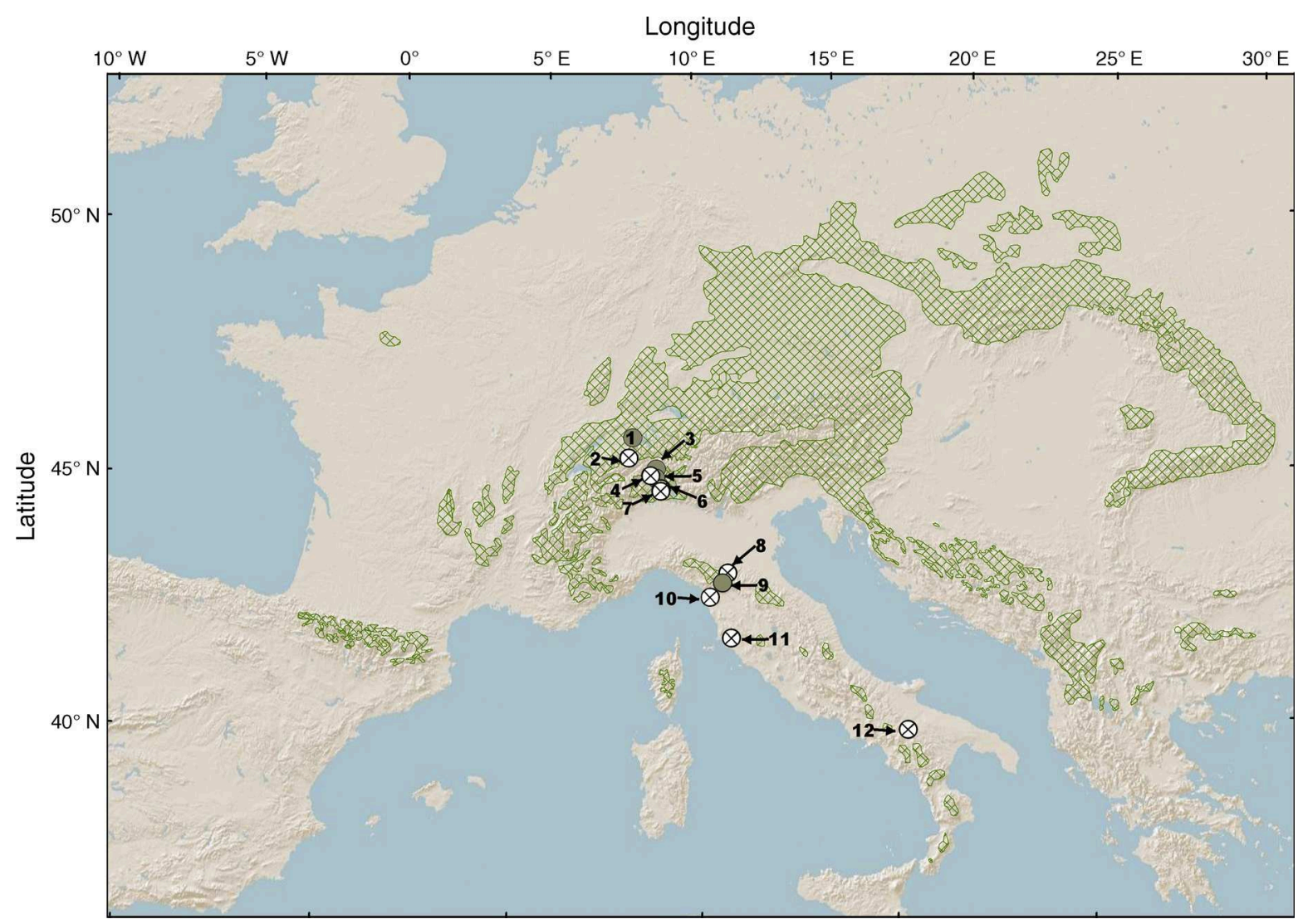

FIG. 1. Map showing the observed range of Abies alba (cross-hatched areas) according to EUFORGEN (2012). The gray circles show sites where Abies alba still forms forests today, and the X's show where they became locally or regionally extinct during the mid to late Holocene. Locations are: 1, Soppensee $(\mathrm{CH})$; 2, Saegistalsee $(\mathrm{CH})$; 3, Foppe $(\mathrm{CH})$; 4, Starlarescio $(\mathrm{CH})$; 5, Piano $(\mathrm{CH})$; 6, Origlio (CH); 7, Muzzano (CH); 8, Pavullo (I); 9, Greppo (I); 10, Massaciuccoli (I); 11, Accesa (I); 12, Monticchio (I); with "(CH)" for Switzerland; and “(I)" for Italy.

before were chosen. A. alba is an average pollen producer and distributor, which is neither significantly under- nor overrepresented in pollen records (Lang 1994, Soepboer et al. 2007), thus, $>5 \%$ may correspond to at least $5 \%$ presence in the vegetation around the site (Table 2). On the basis of the comparison with plant macrofossils (e.g., needles), the empirical pollen limit of Abies alba (onset of continuous curve at $\sim 0.1-1 \%$ depending on counting sums) is commonly interpreted as a reliable indicator of local stands in forested landscapes (Lang 1992, 1994, Tinner and Lotter 2006). According to the available evidence, A. alba was the only Abies species to occur in central Europe and mainland Italy during the past 200000 years (Lang 1994), while fossil evidence for the occurrence of other Abies species is available for, e.g., Sicily (A. nebrodensis; Bertolani Marchetti et al. 1984). On the basis of the available macrofossil and wood evidence, we thus assumed that Abies pollen at our sites reflects A. alba. We cannot exclude that single pollen grains may have derived from other species such as A. nebrodensis in Sicily. However, considering the available palynological evidence (e.g., African pollen transport) we estimate such long-distance effects to $<0.1 \%$ (Tinner et al. 2007).

We used multivariate ordination techniques (detrended correspondance analysis, DCA; program Canoco 4.5; Smilauer 1994) to check for similarities and dissimilarities in the different vegetation types across space and time (Birks and Gordon 1985, ter Braak and Prentice 1988). In our data set, DCA axis 1 has a gradient length of 2.5 standard deviations (SD). According to ter Braak and Prentice (1988), both linear (e.g., PCA) and unimodal methods (e.g., DCA) are valid when the length of gradient is between 1.5 and $3 \mathrm{SD}$. All pollen samples (Table 2) were pooled and percentages of taxa were square-root transformed to stabilize the variance. Pollen abundances of $A$. alba and the cultural indicators Cerealia-t. (t. represents type) and Plantago lanceolata were plotted over all sites and samples to show the changing abundance of these taxa in a spatiotemporal context.

\section{Paleoclimatic reconstructions}

Available pollen-independent paleoclimatic evidence (e.g., reconstructions based on chironomids, lake levels, 


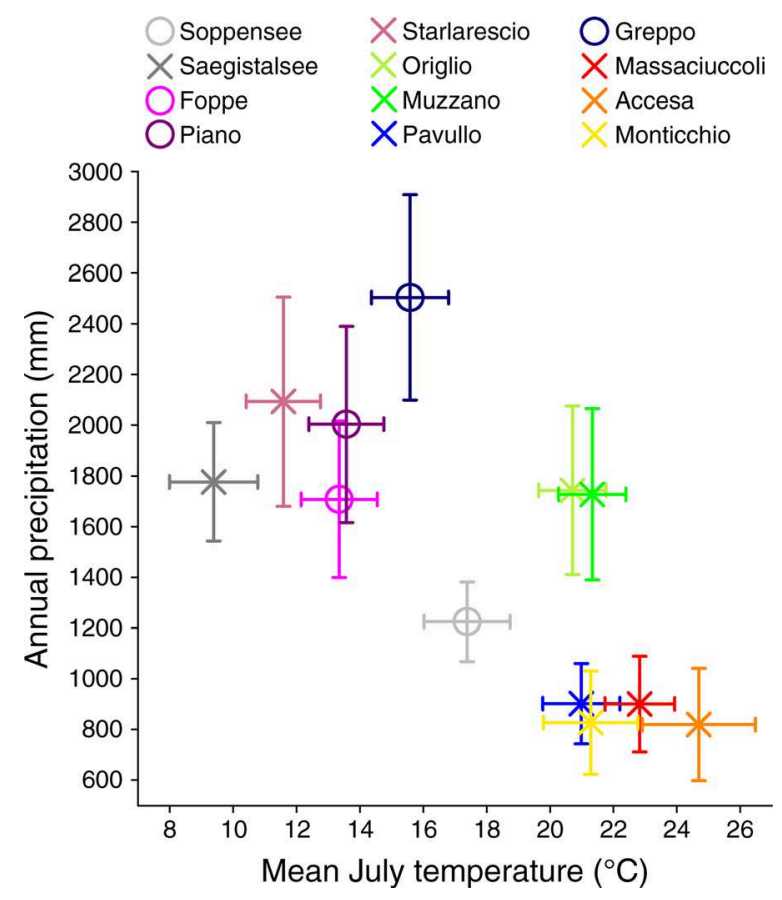

FIG. 2. Mean $( \pm S D)$ annual precipitation vs. mean July temperature at 12 study sites (period 1961-1990). X's show extinct Abies alba populations, and circles show enduring populations. Temperature and precipitation data for study sites in Switzerland were obtained from interpolated climate station data (1961-1990; Thornton et al. 1997; data source is the Swiss Federal Institute for Forest, Snow, and Landscape Research WSL, Birmensdorf, Switzerland). For study sites in Italy, temperatures were obtained from the nearest weather station (1961-1990; Desiato et al. 2007; data source: SCIA System, ISPRA - AMB-MPA - Settore Clima e Meteorologica - Via V. Brancati 4800144 Roma [http://www.scia.sinane.apat.it/ documentazione.asp]). Data for Monticchio were obtained from ENEA (Italian National Agency for New Technologies, Energy and Sustainable Development, Rome, Italy).

stable isotopes) was used to discuss climatic conditions before the local extinctions of $A$. alba in southern Europe and the Alps. We emphasized new chironomid records from the Apennines, Lago Verdarolo, and Lago Gemini, which provide the first quantitative, vegetationindependent temperature reconstructions for Italy for the full Holocene (Samartin 2011). The headcapsules of Chironomidae larvae preserve well in lake sediments for geological periods. The particular taxonomic composition of the fossil assemblage can be used to reconstruct the past chironomid faunal composition of a lake (e.g., Samartin et al. 2012) and, indirectly, to infer past environmental conditions (Fig. 3). Detailed knowledge of chironomid ecology, together with the development of transfer functions, has allowed chironomid-based paleotemperature records to be produced (e.g., Brooks 2006). For chironomid analysis of Lago Verdarolo and Lago Gemini, $0.25-2 \mathrm{~cm}^{3}$ of wet sediment was sieved through a $100-\mathrm{mm}$ mesh size sieve and sorted in a Bogorov tray under a stereomicroscope (400 $\times$ ). Chironomid headcapsules were picked, dried, and mounted in Euparal (ANSCO Laboratories, Manchester, UK) for microscopic identification. At least 50 headcapsules per sample were identified (Heiri and Lotter 2001). For further methodological details, e.g., on taxonomic nomenclature, see Samartin et al. (2012). Mean July air temperature estimates were produced using a chironomid-based temperature inference model developed from newly combined modern calibration data sets from Norway and the Swiss Alps (Heiri et al. 2011). Weighted-averaging/partial least-squares regression (WAPLS; ter Braak and Juggins 1993) was used to develop a chironomid-based transfer function for mean July air temperature from the merged calibration data set. With such transfer functions, estimates of past July air temperatures, with a prediction error typically in the range $1-1.5^{\circ} \mathrm{C}(1 \sigma)$, can be reconstructed from fossil chironomid assemblages (Samartin et al. 2012).

\section{Climatic simulations}

We ran climatic simulations (monthly temperature and precipitation) for $6000 \mathrm{cal}$. BP and the preindustrial period. We chose to simulate the mid-Holocene climatic conditions (6000 cal yr BP) because at that time A. alba was still wide-spread in the sub-Mediterranean and meso-Mediterranean lowlands of the study area (Tinner et al. 1999, Gobet et al. 2000, Allen et al. 2002, Colombaroli et al. 2007, Bellini et al. 2009, Vescovi et al. 2010b). We used climate outputs in four grid cells

TABLE 1. Study sites sorted by latitude.

\begin{tabular}{lcccl}
\hline \hline \multicolumn{1}{c}{ Site } & Latitude (N) & Longitude (E) & Altitude (m asl) & \multicolumn{1}{c}{ Reference } \\
\hline 1) Soppensee (CH) & $47^{\circ} 5^{\prime} 24^{\prime \prime}$ & $8^{\circ} 04^{\prime} 51^{\prime \prime}$ & 596 & Lotter (1999) \\
2) Saegistalsee (CH) & $46^{\circ} 40^{\prime} 47^{\prime \prime}$ & $7^{\circ} 58^{\prime} 35^{\prime \prime}$ & 1935 & Wick et al. (2003) \\
3) Foppe (CH) & $46^{\circ} 47^{\prime} 42^{\prime \prime}$ & $8^{\circ} 27^{\prime} 27^{\prime \prime}$ & 1458 & Vescovi et al. (unpublished data) \\
4) Piano (CH) & $46^{\circ} 19^{\prime} 15^{\prime \prime}$ & $8^{\circ} 37^{\prime} 12^{\prime \prime}$ & 1439 & Valsecchi and Tinner (2010), Valsecchi et al. (2010) \\
5) Starlarescio (CH) & $46^{\circ} 16^{\prime} 26^{\prime \prime}$ & $8^{\circ} 46^{\prime} 26^{\prime \prime}$ & 1875 & Vescovi et al. (unpublished data) \\
6) Origlio (CH) & $46^{\circ} 03^{\prime} 03^{\prime \prime}$ & $8^{\circ} 56^{\prime} 33^{\prime \prime}$ & 416 & Tinner et al. (1999) \\
7) Muzzano (CH) & $45^{\circ} 59^{\prime} 47^{\prime \prime}$ & $8^{\circ} 55^{\prime} 39^{\prime \prime}$ & 337 & Gobet et al. (2000) \\
8) Pavullo (I) & $44^{\circ} 19^{\prime} 12^{\prime \prime}$ & $10^{\circ} 50^{\prime} 18^{\prime \prime}$ & 675 & Vescovi et al. (2010b) \\
9) Greppo (I) & $44^{\circ} 07^{\prime} 07^{\prime \prime}$ & $10^{\circ} 40^{\prime} 40^{\prime \prime}$ & 1442 & Vescovi et al. (2010a) \\
10) Massaciuccoli (I) & $43^{\circ} 49^{\prime} 59^{\prime \prime}$ & $10^{\circ} 19^{\prime} 48^{\prime \prime}$ & 0 & Colombaroli et al. (2007) \\
11) Accesa (I) & $42^{\circ} 59^{\prime} 18^{\prime \prime}$ & $10^{\circ} 53^{\prime} 45^{\prime \prime}$ & 157 & Colombaroli et al. (2008) \\
12) Monticchio (I) & $40^{\circ} 55^{\prime} 53^{\prime \prime}$ & $15^{\circ} 36^{\prime} 19^{\prime \prime}$ & 676 & Allen et al. (2002), Allen and Huntley (2009)
\end{tabular}

Note: Abbreviations are: $\mathrm{CH}$, Switzerland; I, Italy; asl, above sea level. See Fig. 1 for map. 
TABLE 2. Sample information.

\begin{tabular}{|c|c|c|c|c|c|c|}
\hline Site & $\begin{array}{l}\text { Sample depth } \\
\text { range }(\mathrm{cm})\end{array}$ & $\begin{array}{c}\text { Sample age } \\
\text { range (cal yr BP) }\end{array}$ & $\begin{array}{c}\text { Abies alba } \\
\text { pollen }(\%), \\
\text { mean } \pm \text { SD }\end{array}$ & $N$ & $\begin{array}{l}\text { Abies alba } \\
\mathrm{mf}\end{array}$ & $\begin{array}{l}\text { Abies stomata } \\
\text { or wood }\end{array}$ \\
\hline Soppensee (R) & $0.5-14.5$ & -40 to -18 & $7 \pm 1.0$ & 3 & & \\
\hline Soppensee (H) & $356.5-392.5$ & 5714 to 6575 & $25.1 \pm 4.0$ & 10 & yes & yes \\
\hline Saegistalsee (R) & $0.5-1.5$ & -45 to 40 & $1.5 \pm 1.0$ & 3 & & \\
\hline Saegistalsee $(\mathrm{H})$ & $841.5-931.7$ & 6668 to 7350 & $26.6 \pm 6.7$ & 10 & yes & yes \\
\hline Foppe (R) & $0-20$ & -56 to 504 & $1.3 \pm 0.3$ & 3 & & \\
\hline Foppe $(\mathrm{H})$ & $280-330$ & 7260 to 8088 & $28.2 \pm 4.7$ & 6 & yes & yes \\
\hline Starlarescio (R) & $4-10$ & 8 to 41 & $2.2 \pm 1.5$ & 3 & & \\
\hline Starlarescio $(\mathrm{H})$ & $278-326$ & 5810 to 8037 & $18.5 \pm 5.0$ & 4 & yes & yes \\
\hline Piano (R) & $1-8$ & -45 to 0 & $3.0 \pm 2.2$ & 2 & & \\
\hline Piano $(\mathrm{H})$ & $222-240$ & 8413 to 9115 & $23.3 \pm 7.3$ & 10 & yes & yes \\
\hline Origlio (R) & $0-4.8$ & -44 to 29 & $0.0 \pm 0.0$ & 3 & & \\
\hline Origlio $(\mathrm{H})$ & $977-1040$ & 7028 to 7954 & $18.4 \pm 2.4$ & 10 & yes & yes \\
\hline Muzzano (R) & $0.5-6.5$ & -54 to -50 & $0.1 \pm 0.1$ & 7 & & \\
\hline Muzzano (H) & $1190-1280$ & 7013 to 8467 & $24.5 \pm 2.6$ & 6 & yes & yes \\
\hline Pavullo (R) & $135-170$ & 190 to 295 & $5.8 \pm 7.7$ & 2 & & \\
\hline Pavullo (H) & $650-770$ & $6500-8402$ & $61.8 \pm 10.7$ & 8 & yes & yes \\
\hline Greppo (R) & $0-2$ & -53 to 49.5 & $13.5 \pm 1.7$ & 3 & & \\
\hline Greppo (H) & $196-230$ & 8216 to 8538 & $58.9 \pm 4.6$ & 10 & yes & yes \\
\hline Massaciuccoli (R) & $8-24$ & 18 to 162 & $0.4 \pm 0.4$ & 3 & & \\
\hline Massaciuccoli (H) & $412-440$ & 6032 to 6437 & $12.9 \pm 2.3$ & 7 & no & yes \\
\hline Accesa (R) & $10.5-26.5$ & 94 to 317 & $0.4 \pm 0.6$ & 2 & & \\
\hline Accesa $(\mathrm{H})$ & $574.5-583.5$ & $7938-8138$ & $2.1 \pm 1.1$ & 10 & no & no \\
\hline Monticchio (R) & $0.5-25.0$ & 59 to 402 & $0.3 \pm 0.3$ & 5 & & \\
\hline Monticchio (H) & $449.1-501.4$ & 5705 to 6511 & $8.5 \pm 3.1$ & 10 & no & no \\
\hline Monticchio (IS) & $6498.5-6632.0$ & 94124 to 97876 & $33.6 \pm 8.7$ & 10 & no & no \\
\hline Monticchio (IG) & $8182.5-8249.0$ & 115803 to 119203 & $6.13 \pm 2.5$ & 10 & no & no \\
\hline
\end{tabular}

Note: Abbreviations are: R, recent; H, Holocene; IS, Interstadial; IG, Interglacial, mf, macrofossils.

$\left(3.75^{\circ} \times 3.71^{\circ}\right.$, area of $\sim 126000 \mathrm{~km}^{2}$ each) that cover the locations of the study sites (Fig. 4) from simulations with the global coupled carbon cycle-climate model National Center for Atmospheric Research (NCAR) CSM1.4-carbon (Boville and Gent 1998, Doney et al. 2006). This model has been shown to produce stable results and to be able to simulate the global climate and carbon cycling reasonably well (Doney et al. 2006). The model was initialized with preindustrial greenhouse forcing $\left(p \mathrm{CO}_{2}=278 \mathrm{ppm}\right)$ to reach steady state and is then run for several hundred years under constant external forcings and freely evolving $\mathrm{CO}_{2}$. The orbital forcing was set to $1820 \mathrm{AD}$ and $6000 \mathrm{cal} \mathrm{yr} \mathrm{BP}$ conditions (Berger 1978) in the preindustrial and midHolocene simulations, respectively. All other settings were identical in both simulations, so that the difference between the two simulations provides an estimate of the altered climatic conditions due to the different orbital parameters.

\section{Ecological niche concept}

On the basis of the ecological niche theory, we adopted the climatic niche concept of Pearson and Dawson (2003) for correlative models (e.g., bioclimatic envelope models, sometimes also referred to as species distribution models, SDMs; Alba-Sánchez et al. 2010) in which the observed species distributions are constrained by climatic and non-climatic factors, including biotic interactions such as competition. The climatic niche is thus the climatic component of the realized ecological niche, while the fundamental niche is not directly considered here. Investigating realized niches has the advantage of considering niches that may be realized in future; conversely, pure fundamental niche analyses may fail to deliver accurate future distribution predictions of species (Pearson and Dawson 2003), because important non-climatic factors such as biotic competition for resources are not considered. However, species' fundamental niches are implied in physiologically based dynamic vegetation models such as LandClim (Schumacher et al. 2004, Elkin et al. 2012). If compared to correlative bioclimatic envelope models, dynamic vegetation models have the advantage that they do not require the assumption that the species are in equilibrium with today's climate and also consider competition and other environmental factors to assess the realized ecological niche of species. Since it is debated which approach is superior (Prentice et al. 1992, Sykes et al. 1996, Pearson and Dawson 2003), in this study we applied both correlative bioclimatic envelope and physiologically based dynamic vegetation models. Thus, our realized-niche assessment of $A$. alba is based not only on (correlative) past and present range analyses, but also on a physiologically based dynamic vegetation model.

\section{Correlative bioclimatic envelope modeling}

We used the present distribution of $A$. alba (EUFORGEN 2012; Fig. 1) to infer the realized (present) climatic niche of the species. Seven climatic parameters were 


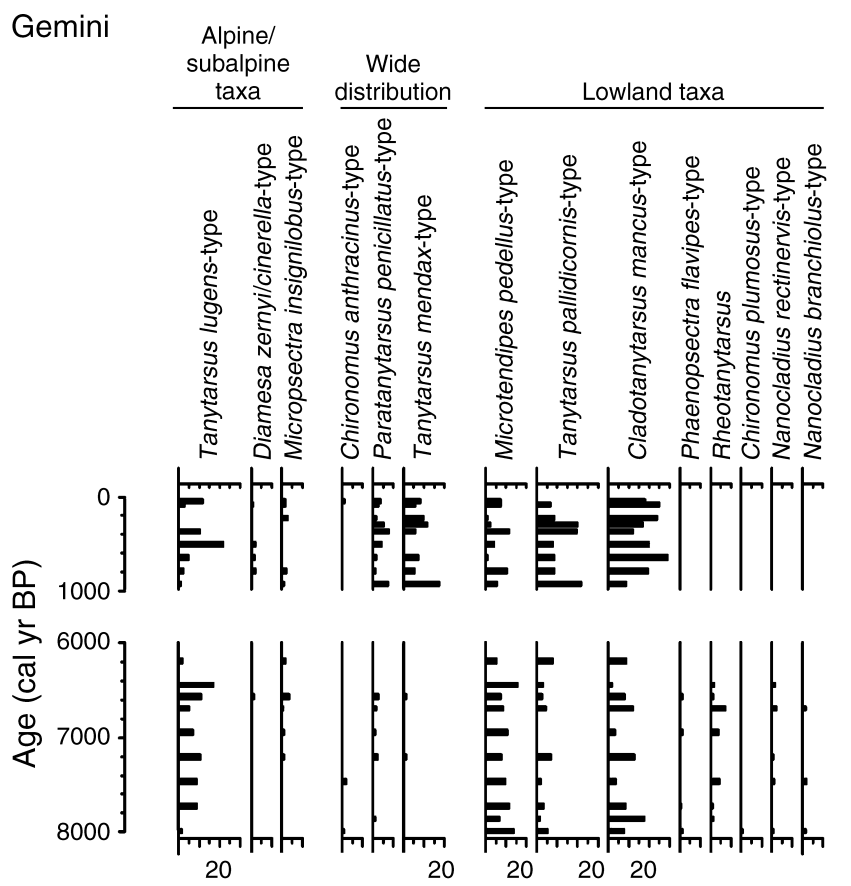

Relative abundance (\%)

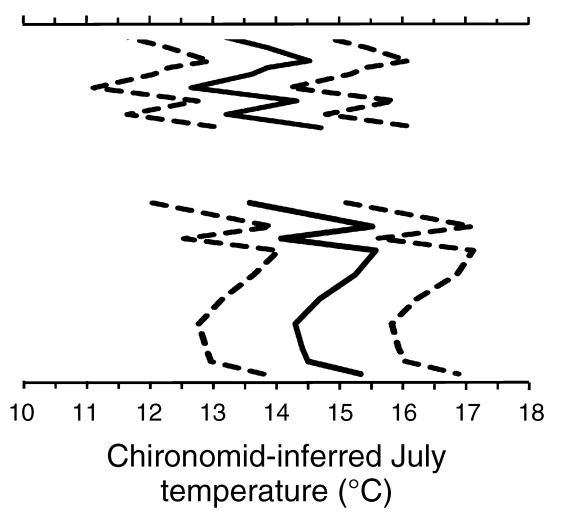

Verdarolo
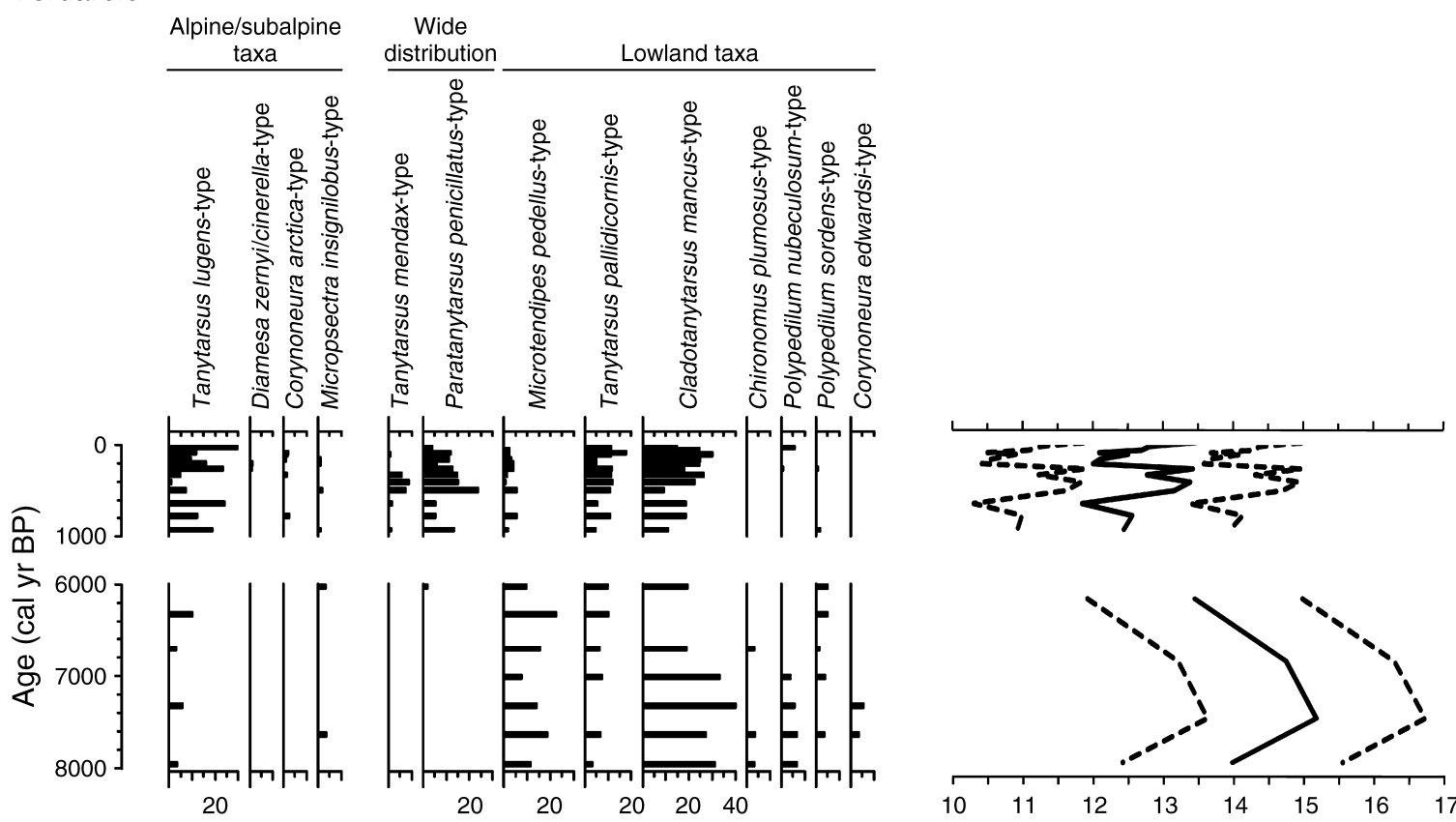

Relative abundance (\%)

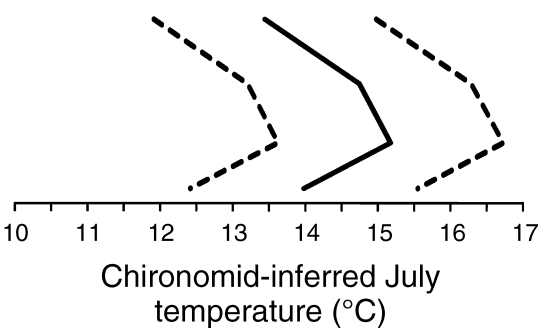

FIG. 3. Chironomid assemblages from two lakes in the Tuscan-Emilian Apennines (Samartin 2011) for the periods 0-1000 and $6000-8000$ cal yr BP and corresponding transfer-function-inferred July temperature estimates with errors ( \pm SE). Lago Gemini Inferiore (1349 $\mathrm{m}$ above sea level [asl]) and Lago Verdarolo $(1390 \mathrm{~m}$ asl) are at a $6 \mathrm{~km}$ distance from each other and at a $60 \mathrm{~km}$ distance from Lago di Massaciuccoli at the Mediterranean Sea shore (see Fig. 9). Only selected taxa are shown. 

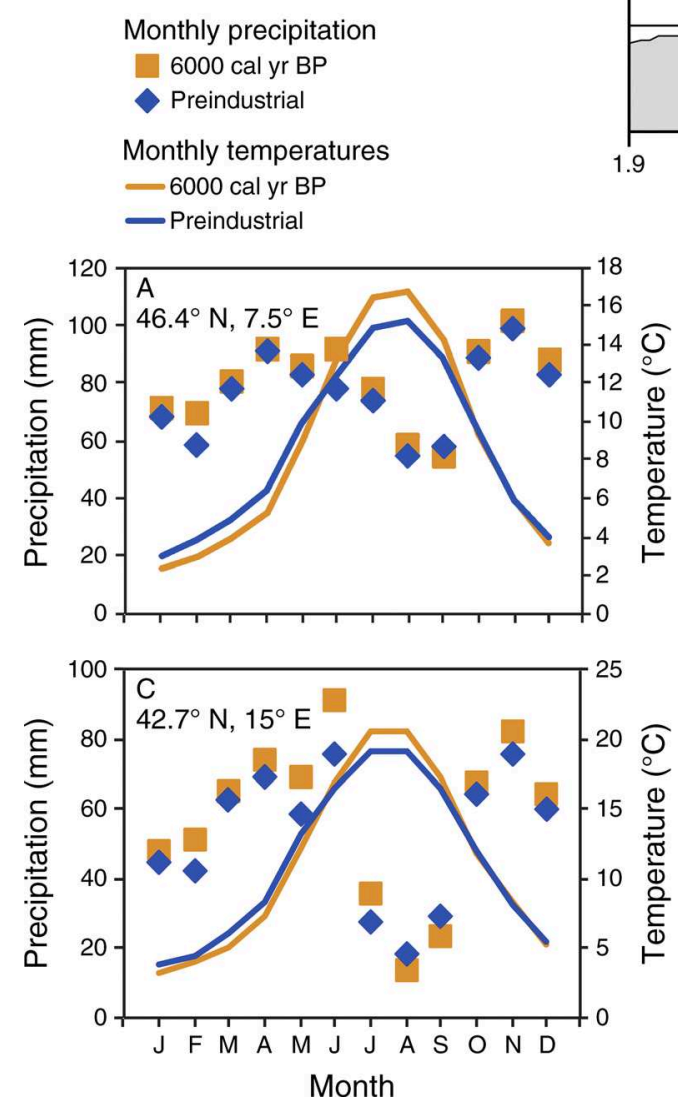
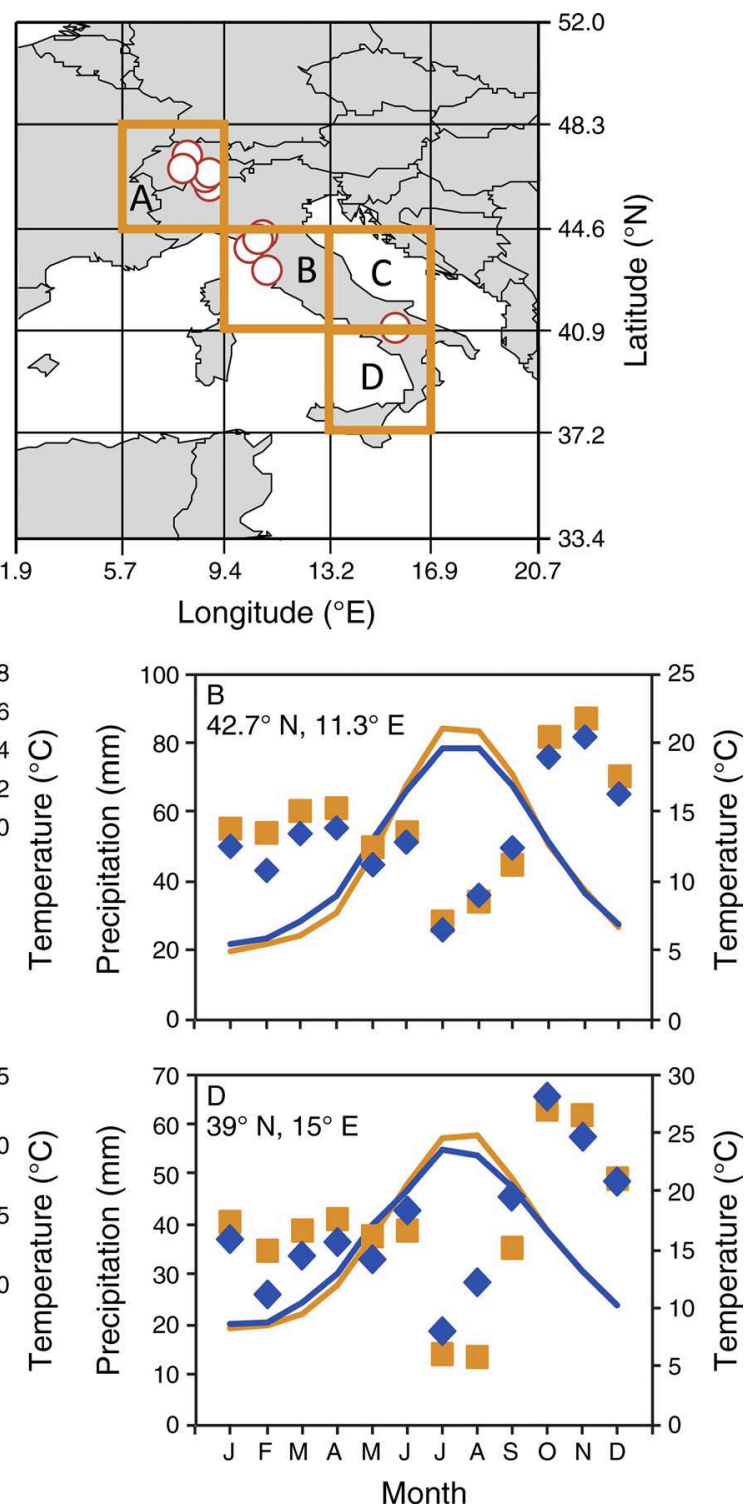

FIG. 4. Top: Map showing the grid squares selected for the analysis of regional climatic conditions during the mid-Holocene (6000 cal yr BP) from a global climate model simulation (NCAR CSM1.4). The sea surface is not included in the temperature and precipitation analysis. (A-D) Monthly temperature and precipitation simulations for the mid-Holocene (6000 cal yr BP) compared to the preindustrial period, calculated as average values for terrestrial sections of the studied grid cells only. Average altitude of the grid cells is $959 \mathrm{~m}$ asl for panel (A), $162 \mathrm{~m}$ asl for panel (B), $218 \mathrm{~m}$ asl for panel (C), and $121 \mathrm{~m}$ asl for panel (D). Temperatures simulated for the preindustrial period are in agreement with the situation during the 17th and 18th centuries as recorded through long-term measurements.

derived for the area covered by $A$. alba from gridded climatic data with a spatial resolution of 10 minutes covering an area of $\sim 170 \mathrm{~km}^{2}$ for the period 1961-1990 (New et al. 2000, 2001; Climatic Research Unit [CRU], available online). ${ }^{12}$ The seven parameters were mean temperature (monthly and annual, in ${ }^{\circ} \mathrm{C}$ ), mean precipitation (monthly and annual, in $\mathrm{mm}$ ), ground frost (number of days with frost/month), sunshine duration (percentage/month), relative humidity (per-

\footnotetext{
${ }^{12}$ http://www.cru.uea.ac.uk/cru/data/hrg/tmc/
}

centage/month), mean diurnal temperature $\left({ }^{\circ} \mathrm{C} /\right.$ month), and wet days (number of days $>1 \mathrm{~mm}$ precipitation/ month). All parameters with the exception of annual temperature and annual precipitation were analyzed at a monthly level; thus, the analysis comprised 86 climate variables $(7 \times 12+2)$. To examine the potential range of A. alba, a new map was created with ArcGIS 10 (Fig. 5). The modern potential range (green in Fig. 5) was formed by areas in Europe (grid cells, $\sim 170 \mathrm{~km}^{2}$ ) in which all 86 climatic variables simultaneously reach values that correspond to the values within the limits of the 


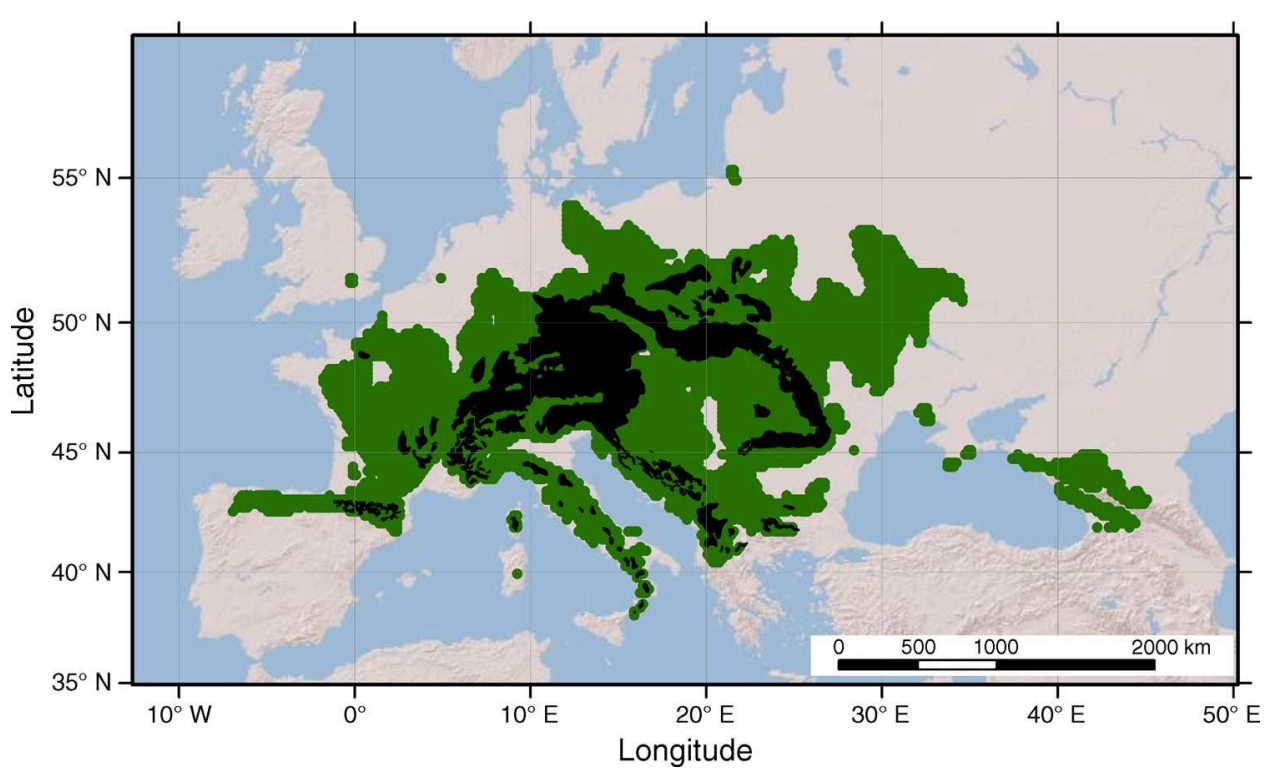

FIG. 5. Map showing the realized and potential spatial range of Abies alba. Realized range of $A$. alba is shown in black (EUFORGEN 2012). Our estimation of the modern potential range (in green) was calculated based on the present occurrence of the species and local climate at these locations as reflected by 86 climatic variables (mean monthly and annual precipitation, wet days, mean monthly and annual temperature, mean diurnal temperature, relative humidity, sunshine duration, and ground frost). At the eastern edge of the potential distribution in the Caucasus region east of the Black Sea, the vicariant species A. nordmanniana covers the habitats suitable for A. alba (Liepelt et al. 2009, 2010).

(present) realized spatial range of $A$. alba (black in Fig. 5). The consideration of each of the 86 climatic variables contributed to a substantial reduction of the species' potential range, while adding growing degree days (GDD) $>5^{\circ} \mathrm{C}$ as an additional variable had no effect on the estimated potential range. Hence, we regarded GDD as redundant. Our bioclimatic modeling approach is climatically more inclusive and ecologically more conservative than approaches with significantly less parameters (e.g., Svenning and Skov 2004, Pearman et al. 2008, Normand et al. 2011) and should therefore result in a smaller estimation of the potential range. The same approach used for $A$. alba was applied to generate potential distribution maps of three other paramount European tree species: Picea abies, Fagus sylvatica, and Quercus robur. These species were included to assess whether their differences between realized and potential range (according to observations) was comparable to that of $A$. alba. The differences between realized and potential ranges, a measure of how well species fill their potential spatial ranges (Normand et al. 2011), are given in percentages.

\section{Physiologically based dynamic vegetation and landscape modeling}

We assessed the modern competitive ability of $A$. alba in regions where it became locally extinct using the dynamic vegetation and landscape model LandClim (Schumacher et al. 2004, Schumacher and Bugmann 2006, Elkin et al. 2012). We simulated forest dynamics for the past 7000 years on the basis of competitive interactions among $A$. alba and a suite of extant
Mediterranean tree species in a 1500-ha landscape situated in the limestone hills east of Lago di Massaciuccoli (Henne et al. 2013). LandClim simulates stand-level forest dynamics (e.g., establishment, competition, mortality) in $25 \times 25 \mathrm{~m}$ grid cells, and disturbances (e.g., fire, windthrow $)$ at a landscape scale $\left(\sim 30 \mathrm{~km}^{2}\right.$; Schumacher et al. 2006). A suite of species-specific climatic variables limit growth in LandClim, including GDD and temperature of the coldest month (for details see Henne et al. 2013). The landscape chosen for simulation rises from 0 to $353 \mathrm{~m}$ above sea level (asl; mean $=84 \mathrm{~m}$ asl) and contains steep slopes with shallow soils, and deeper colluvial deposits in low topographic positions.

The climate scenario for our simulation combines chironomid-inferred July temperature anomalies from a nearby lake (Lago Verdarolo; Samartin 2011, Henne et al. 2013) with weather station data from Pisa San Giusto Airport. We added the chironomid-inferred temperature anomalies to monthly values, generated from weather station data (1951-2007) for the six warmest months (for details see Henne et al. 2013). Resulting mean July temperatures vary between $22.2^{\circ} \mathrm{C}$ and $24.3^{\circ} \mathrm{C}$ (modern mean $=22.8^{\circ} \mathrm{C}$ ), and the mean annual precipitation is $892 \mathrm{~mm}$. We used the modern distribution and variability of temperature for the six coldest months, and precipitation for all months. Our application of a dynamic vegetation model provides a quantitative and independent assessment based on the ecological and ecophysiological parameters that drive the model (Anderson et al. 2006), whether $A$. alba would be able to grow on the Mediterranean coast in the absence of excessive browsing and fire. 


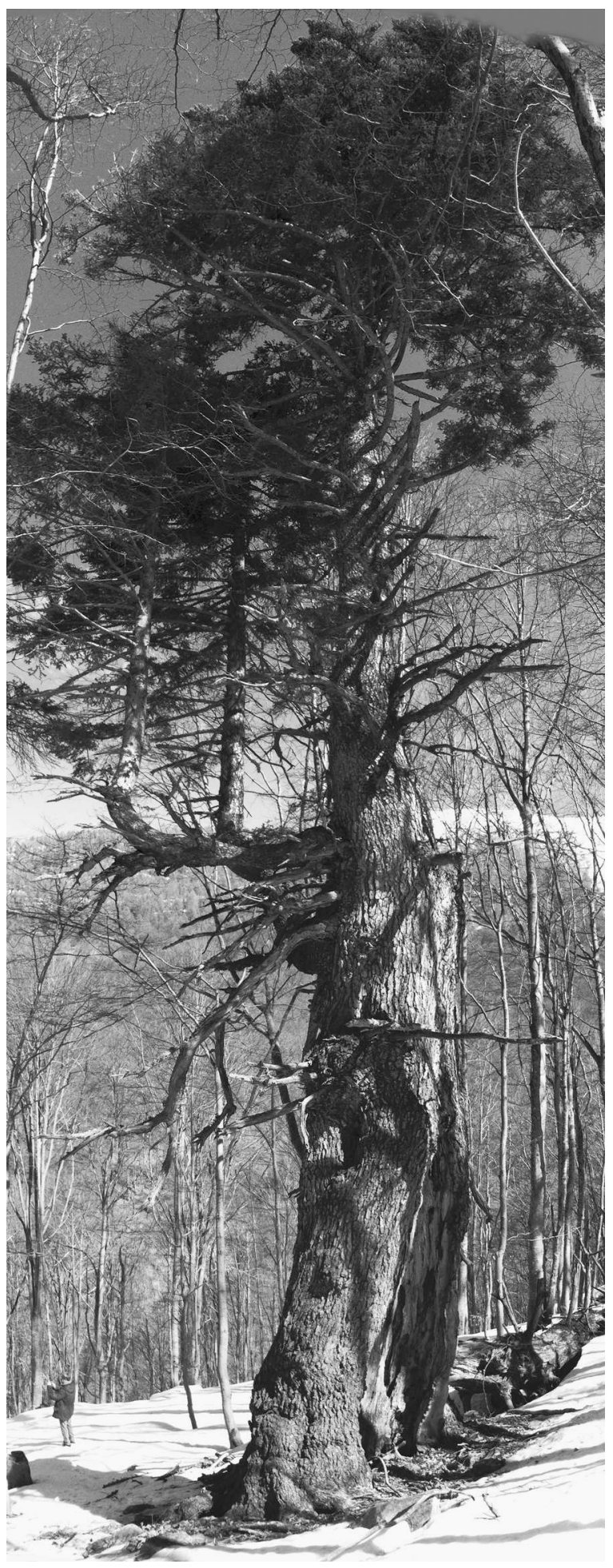

Plate 1. Monumental silver fir tree in a beech forest in Vegnasca, Canton Ticino, southern Switzerland. This silver fir tree has an age of ca. 400 years and a circumference of $7.6 \mathrm{~m}$. Photo credit: G. Carraro.

\section{RESULTS AND INTERPRETATION}

\section{Pollen-inferred vegetation}

Our analyses show the former pollen and thus presumably vegetational significance of Abies alba that spanned from average values of $\sim 2 \%$ to $60 \%$ (Table 2). At most sites, the species attained an average relevance between $\sim 10 \%$ and $30 \%$ during the mid-Holocene. The lowest values are reached at Accesa in Tuscany, the highest at Pavullo and Greppo in the Tuscan-Emilian Apennines, where the species probably had its glacial refugia (Lowe and Watson 1993, Vescovi et al. 2010a, b). The moderate abundance of the species recorded in the Accesa lake sediments $(\leq 5 \%)$ is indicative of the extralocal relevance, while locally it was probably more abundant as suggested by pollen values reaching $>20 \%$ in the peat deposits close to the lake shore (DrescherSchneider et al. 2007). Abundant pollen (>30\%) and wood of Abies was also found in peat deposits close to Lago di Massaciuccoli and in the entire coastal area between southeastern Liguria and northwestern Tuscany (Bellini et al. 2009), again indicating high local abundance. Together with wood that was also found in Massaciuccoli lake sediments (Colombaroli et al. 2007) this provides evidence that $A$. alba occurred locally along the Mediterranean coast in Liguria and Tuscany during the mid-Holocene. Similarly, abundant findings of $A$. alba needles and stomata unambiguously document the former importance of the species at subMediterranean sites in northern Italy and southern Switzerland (e.g., Schneider and Tobolski 1985, Lang 1992, Tinner et al. 1999, Gobet et al. 2000) and at treeline in the Alps (Table 2, Fig. 2; e.g., Wick et al. 2003).

Pollen assemblages show that natural or quasi-natural plant communities that included $A$. alba ranged from treeline (together with, e.g., Larix decidua, Pinus cembra, Picea abies), to mountain (with, e.g., Fagus sylvatica), colline (with, e.g., Quercus robur, Q. petraea, Fraxinus excelsior, Tilia, Ulmus, Acer, Alnus glutinosa, Hedera helix), sub-Mediterranean (with Quercus pubescens, $Q$. cerris, Ostrya carpinifolia, Fraxinus ornus, Ilex aquifolium, Vitis), and meso-Mediterranean vegetation (with Quercus ilex, Phillyrea, Pistacia, Arbutus, Cistus, and occasionally Olea europaea).

Ordination analyses of pollen samples show a clear distinction between natural or quasi-natural (midHolocene and older; see Table 2) and humanized (recent) conditions at our study sites (Fig. 6). One recent sample from Pavullo falls close to the midHolocene samples. This top sample was probably contaminated with older material during the construction of the parking lot that covers the site today (Vescovi et al. 2010b), for it completely lacks cultural indicators (e.g., Castanea sativa, Plantago lanceolata, Cerealia-t.), which are typical for modern and historical pollen assemblages in the region. The ordination analysis of associated species shows that the abundance of $A$. alba, 


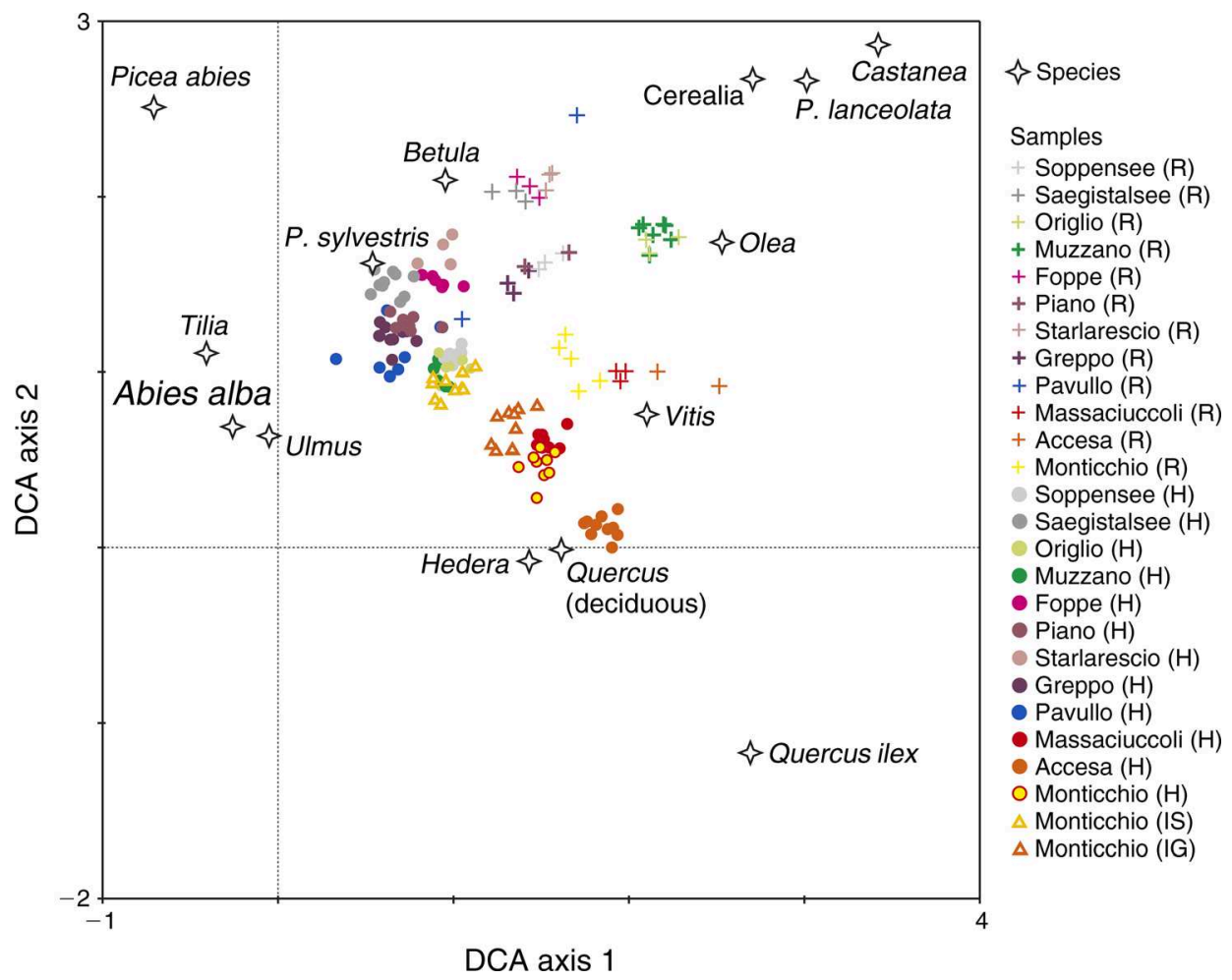

FIG. 6. Detrended correspondence analysis (DCA) biplot of pollen samples from lake sediment records in Switzerland and Italy (Table 2). The analysis represents the trajectory of vegetation changes at the study sites during the past. Solid dots indicate Holocene $(\mathrm{H})$ samples before the first evidence of human impact; corresponding recent $(\mathrm{R})$ samples from the same site are labeled with crosses. Triangles show Interstadial and Interglacial samples at Lago di Monticchio, and stars show a selection of important taxa (species).

which is highest at the quasi-natural sites, declines with increasing significance of anthropogenic indicators such as Plantago lanceolata and Cerealia-t. (Fig. 7).

Generally, ordination analyses show a pattern that resembles the geographical position of the sites, with the Alpine locations on the top and the lowland Mediterranean sites on the bottom of axis 2, an order that is inverted on axis 1 (Fig. 6). The spatial pattern of the samples can be explained by environmental and land-use factors that influence the occurrence of plant species over time and space. The order of the samples along axis 1 resembles that of temperature, with sites arranged from coldest (e.g., Saegistalsee, Starlarescio, Greppo, Piano) to warmest (e.g., Origlio, Muzzano, Massaciuccoli, Monticchio, Accesa) conditions. This environmental gradient is mirrored by the taxa, ranging from boreal (e.g., Picea abies, Betula) to temperate (Tilia, Ulmus, Quercus robur-t.), and Mediterranean trees and shrubs (e.g., Quercus ilex-t., Pistacia).

\section{Climatic conditions}

Today's climatic conditions across the study region follow a distinct gradient of increasing temperature with decreasing altitude and latitude. This gradient is not linear. South of the Alps, in northern Italy and southern Switzerland, temperatures are closer to those of sites farther south than to those of adjacent sites north of the Alps (Fig. 2). This is a result of the proximity of the Mediterranean Sea and the barrier effect of the Alps, which shelter the Italian Peninsula from cold northern and eastern winds. Moreover, in the southern Alpine piedmonts, northerly cold and moist winds are converted into warm and dry falling winds (foehn). Locally, large end-moraine lakes at the foothills of the Alps (e.g., lakes Maggiore, Lugano, Como, Garda) also contribute to mild conditions during the winter, reducing the average number of days with a daily temperature maximum $<0^{\circ} \mathrm{C}$ to $0-2^{\circ} \mathrm{C} /$ winter at, e.g., Muzzano and Origlio (Meteoschweiz, available online). ${ }^{13}$

Present-day climatic conditions cannot be extrapolated to the early and mid-Holocene or even to the Eemian, when important orbital parameters were different (e.g., higher summer insolation during the mid-Holocene; Kutzbach and Webb 1993, Renssen et al. 2009). However, it is plausible that the major altitudinal and latitudinal gradients stayed more or less stable over the past $\sim 120000$ years. To avoid circularities, vegetationbased reconstructions (e.g., Allen et al. 2002, Davis et al. 2003) cannot be used to assess the climatic conditions that occurred when natural or quasi-natural $A$. alba

\footnotetext{
${ }^{13} \mathrm{http}: / /$ www.meteoschweiz.admin.ch/files/kd/normwerte/ norm6190/nvrep_tnd00xm0_en.pdf
} 
forests grew at our sites. The new Verdarolo chironomid-inferred climate reconstruction suggests that summer temperatures were $1-2^{\circ} \mathrm{C}$ warmer than today during the mid-Holocene (Fig. 3). This chironomid-inferred climatic reconstruction has been validated using the same approach at a second site, Gemini, located only 7 $\mathrm{km}$ from Verdarolo. The strong agreement between the two paleoclimatic time series (Samartin 2011) shows that the results are robust and can be reproduced in space and time. Both reconstructions indicate a gradual cooling in mean July air temperature in the study region by $\sim 1-2^{\circ} \mathrm{C}$ from the mid-Holocene to the present. Although non-pollen evidence is scarce (e.g., Magny et al. 2007, 2011c, Marchetto et al. 2008, Samartin 2011, see Discussion), climate modeling-based reconstructions can be used to constrain past climatic conditions and to overcome this gap.

Climate simulations for the preindustrial period using the NCAR CSM1.4-carbon model are in reasonable agreement with observation-based data for the same period (Doney et al. 2006). Although some biases exist in the simulated physical climate, they are small for our study region. For example, the model slightly overestimates annual mean temperatures at the northern study sites (Fig. 4A), while temperatures at southern sites are somewhat too low, and precipitation is slightly overestimated in the whole region. However, the model delivers adequate results for the purpose of comparing climatic conditions in this region under different orbital forcings, even if the model resolution is rather coarse. Paleoclimate model outputs suggest that the midHolocene summers were $1-2^{\circ} \mathrm{C}$ warmer than the preindustrial period (ca. AD 1800; Fig. 4), while winters were cooler. Precipitation during the mid-Holocene was comparable to today, with a seasonal shift towards moister winters and drier summers especially south of $45^{\circ} \mathrm{N}$ at the Mediterranean sites. Mid-Holocene moisture availability was thus higher during winter and lower during summer when compared with today.

\section{Bioclimatic modeling, potential range, and dynamic vegetation simulations}

The present occurrence of Abies alba in Europe (including the Mediterranean) has been related to summer temperatures between $14^{\circ} \mathrm{C}$ and $19^{\circ} \mathrm{C}$ (Mayer $1984 b$ ), which is in good agreement with our bioclimatic estimates, ranging from $14.3^{\circ} \mathrm{C}$ to $18.3^{\circ} \mathrm{C}$ for July (1 standard deviation, SD; Fig. 8). Annual precipitation ranges between 640 and $1170 \mathrm{~mm}(1 \mathrm{SD})$, and during the summer (June-August) precipitation is $\sim 150-450 \mathrm{~mm}$. At the Mediterranean sites where $A$. alba formed natural or quasi-natural forests during the mid-Holocene, today's July temperatures are much higher, ranging between $20.5^{\circ} \mathrm{C}$ and $23.5^{\circ} \mathrm{C}\left(1 \mathrm{SD}\right.$ around mean of $22^{\circ} \mathrm{C}$; Fig. 8), while annual precipitation spans from 690 to $1607 \mathrm{~mm}$ ( $1 \mathrm{SD}$ ) and summer precipitation is $\sim 125-500$ $\mathrm{mm}$, and thus comparable with areas where the species still forms forests today.
Our bioclimatic modeling also suggests that the potential spatial range of $A$. alba is much wider than the realized range (Fig. 5). This limited filling of the potential (geographical) range may be attributed to nonclimatic causes, such as dispersal mechanisms, location of refugia, disturbance, land use, or unsuitable biotic or abiotic habitat conditions (e.g., competition, pathogens, soils). The bioclimatic envelope modeling analysis of other key species (e.g., Picea abies, Quercus robur, Fagus sylvatica) reveals a far better filling of their observationbased potential ranges (Table 3), and thus of their (present) realized climatic niche (Pearson and Dawson 2003), suggesting that non-climatic factors such as land use or disturbance are more important for A. alba than for the other key tree species. This finding is even more pronounced, if only temperature and precipitation are used for the estimation of a less conservative potential spatial range of Abies alba (Table 3).

Dynamic simulations of vegetation with LandClim suggest that, in the absence of excessive disturbance (browsing, fire), A. alba could still form forests at Massaciuccoli, a coastal Mediterranean site in Tuscany (Figs. 1 and 2; Henne et al. 2013). A chironomidinferred temperature reconstruction (Samartin 2011) from the nearby site Verdarolo in the Tuscan-Emilian Apennines $(60 \mathrm{~km}$ distant) allows a quantitative assessment of long-term climatic impacts on vegetation. Our simulation experiment implies that the species had the potential to form mixed forests together with Quercus ilex throughout the mid and late Holocene (Fig. 9A). In the dynamic vegetation simulation (Fig. 9A), the pronounced climatic cooling (and resultant increase in moister availability) after 6000 cal. BP allowed $A$. alba to expand at the expense of evergreen oaks (Quercus ilex). Landscape-resolved vegetation simulations (Fig. 9B-E) show that during the midHolocene, the species was probably dominant on northerly slopes especially above $\sim 200 \mathrm{~m}$ asl, but also at low altitudes close to the Mediterranean Sea shore, where soils were sufficiently deep (Fig. 9C, D; high bucket size, for instance, in valley bottoms). In the model Abies alba expands to shallower soils and lower altitudes (Fig. 9E) during the late Holocene, increasing its forest biomass share in the Massaciuccoli area from $5-10 \%$ at 6000 cal BP to $30-40 \%$ (Fig. 9A). This outcome contradicts paleobotanical evidence at Massaciuccoli, where a dramatic collapse of $A$. alba is documented between 6000 and 5000 cal BP (Colombaroli et al. 2007). However, if browsing and fire are increased in the model, disturbance-sensitive $A$. alba collapses within a few decades (Henne et al. 2013) and finally disappears from the Mediterranean coastland.

\section{DisCUSSION}

\section{Extinct Mediterranean Abies alba communities}

Pollen and macrofossil data indicate a pre-agrarian occurrence of distinctive thermophilous Abies alba communities in the Italian Peninsula (Tinner et al. 

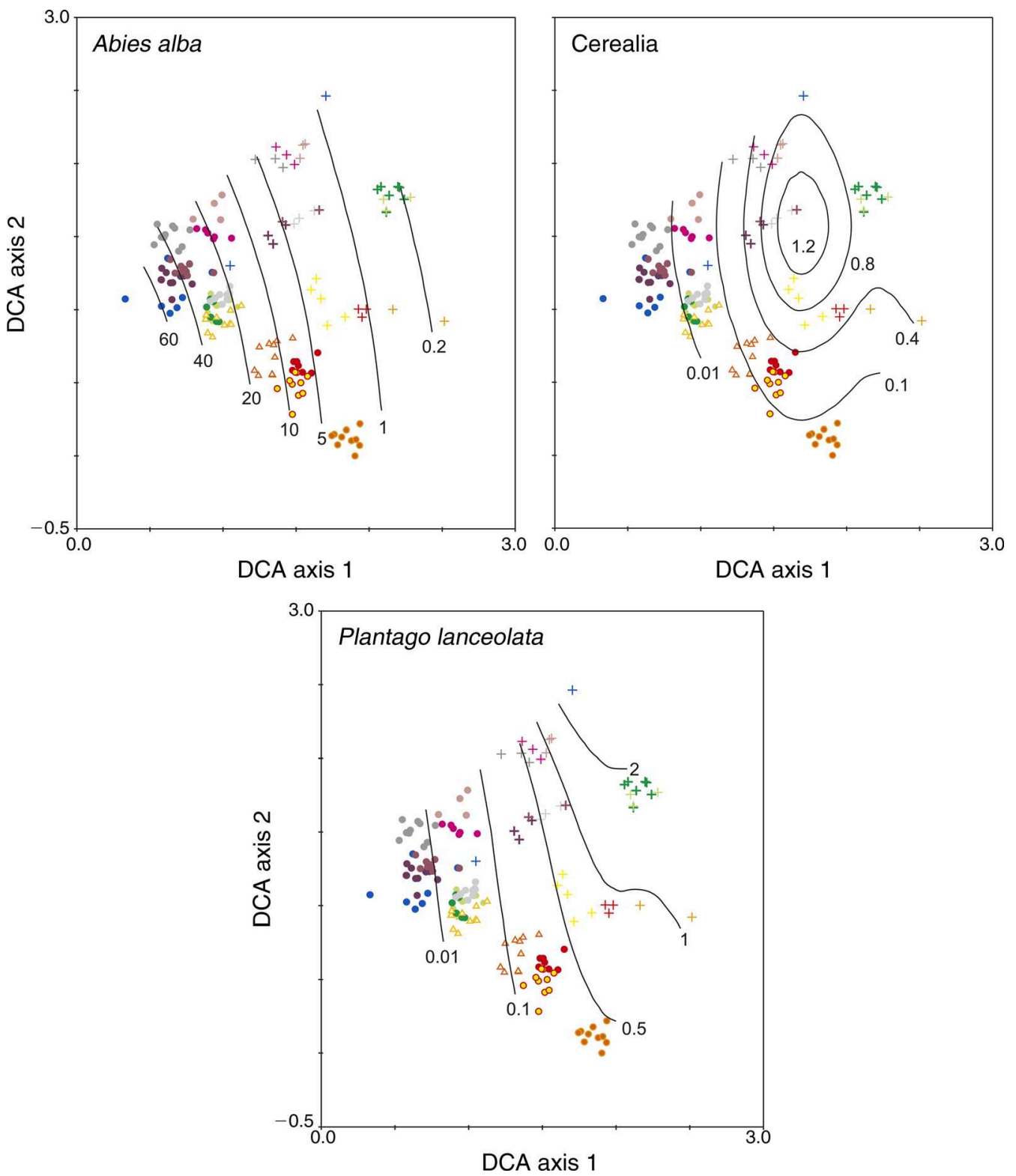

FIG. 7. Selected taxa (species) abundances overlaid on the DCA ordination plot. Contour lines of the percentage of species values were obtained with a generalized additive model with three degrees of freedom, and stepwise selection using the Akaike information criterion. Abies alba is abundant at the mid-Holocene, Interstadial, and Interglacial sites, whereas Plantago lanceolata (indicator for arable and pastoral farming) and Cerealia-type are abundant in the recent samples. For sample colors and site names see Fig. 6.

1999, Gobet et al. 2000, Wick and Möhl 2006, Colombaroli et al. 2007, Mariotti-Lippi et al. 2007, Amorosi et al. 2009, Bellini et al. 2009, Vescovi et al. $2010 \mathrm{~b}$ ). In these extinct communities, the coniferous tree grew with thermophilous deciduous (e.g., Quercus pubescens, $Q$. robur, $Q$. cerris, $Q$. petraea, Tilia, Ulmus, Fraxinus, Acer, Vitis) and/or evergreen broadleaved (e.g., Quercus ilex, Phillyrea, Olea, Arbutus, Cistus, Ilex aquifolium, Hedera helix) taxa, suggesting that the climatic niche of the species is considerably wider than previously described. In a contrasting environmental setting, A. alba also formed forests with Pinus cembra and Larix decidua under very harsh timberline conditions (Fig. 2; Wick et al. 2003). At present, such communities are also lacking in the Alps, although single $A$. alba trees regularly occur close to treeline. This finding is thus ecologically less striking than the former occurrence of $A$. alba at the Mediterranean coast.

According to the prevailing paradigm, A. alba is a typical tree of the cool and moist mountain belt (e.g., Mayer 1984b, Pignatti 1997, Ellenberg 2009, Ellenberg and Leuschner 2010, Frey and Lösch 2010), which has 

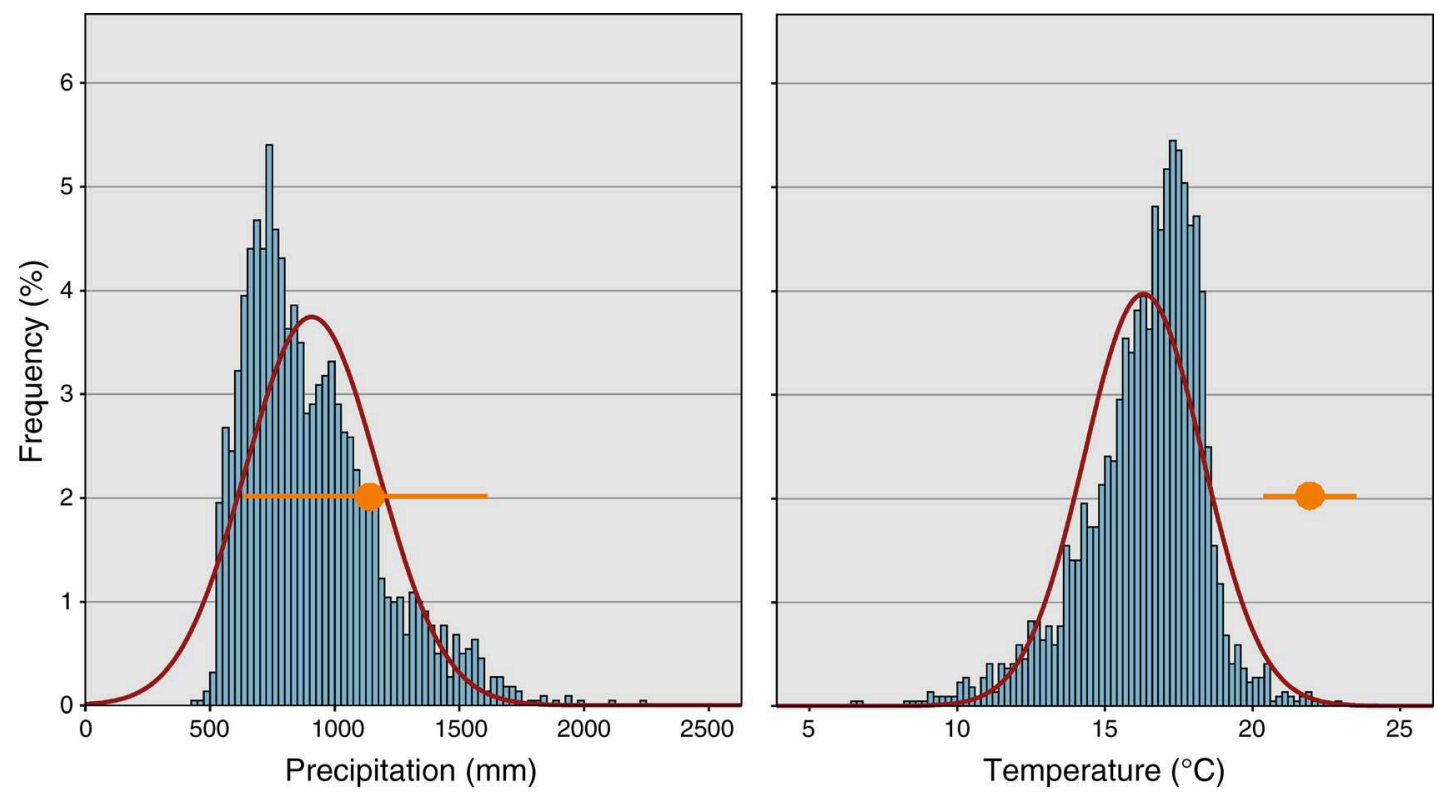

FIG. 8. Precipitation and July temperature distribution in the extant range of Abies alba and at Mediterranean sites that suffered extinction. The histograms mark the present precipitation and temperature niche of the species, and the red curved lines show the (hypothetical) modeled normal distributions. The orange dots with line show today's precipitation and July temperatures (mean $\pm \mathrm{SD}$ ) for sites where the species was able to co-dominate the natural or quasi-natural vegetation during the mid-Holocene but is extinct today. Mean ( \pm SD) annual precipitation (period 1961-1990) is $907 \pm 266 \mathrm{~mm}$, and mean July temperature $16.3^{\circ} \pm$ $2.0^{\circ} \mathrm{C}$ in the present range of Abies alba, and $1148 \pm 459 \mathrm{~mm}$ and $22.0^{\circ} \pm 1.5^{\circ} \mathrm{C}$ at the Mediterranean sites (orange dots with lines) where it disappeared during the Late Holocene. The SD interval derived from our bioclimatic envelope modeling for the present realized niche of the species $\left(14.3-18.3^{\circ} \mathrm{C}\right)$ is very close to the estimates of the limits for Abies alba forest growth in Europe according to ecological literature $\left(14-19^{\circ} \mathrm{C}\right.$; Mayer $\left.1984 b\right)$. Note that temperatures during the mid-Holocene were $\sim 1.5^{\circ} \mathrm{C}$ higher than between 1961 and 1990 at the Mediterranean sites (see Figs. 3 and 9; Samartin 2011), while summer precipitation was lower. The source for Abies alba range data is EUFORGEN (2012), and for climatic data, Climatic Research Unit (CRU; see footnote 12) and New et al. $(2000,2001)$.

no potential to form forests in the sub-Mediterranean and Mediterranean lowlands. However, this conclusion mainly derives from the current distribution of $A$. alba, and does not take paleoecological evidence into account. Only few ecological works have questioned this belief on the basis of the relict presence of single old $A$. alba trees, site names, old photographs, and archive documents indicating the occurrence of this species in the lowland vegetation of southern Switzerland and Mediterranean Italy (Rovelli 1995, Carraro et al. 1999).

There are no natural modern analogues for the extinct sub-Mediterranean and meso-Mediterranean $A$. alba forests, although other Mediterranean Abies species are able to form forests under comparable Mediterranean climatic and vegetational conditions (e.g., A. cephalonica, A. borisii-regis; Mayer 1984b). However, A. alba is able to grow at the Mediterranean coast as shown by the occurrence of forests that were planted 200 years ago and in which Mediterranean species such as evergreen Quercus ilex, Arbutus unedo, Viburnum tinus, and Erica arborea co-occur (Cortini Pedrotti 1967). In these Mediterranean coastal forests, Abies alba is the tallest tree (reaching $\sim 30 \mathrm{~m}$ ) and regenerates spontaneously building uneven-aged stands.

Recent dynamic modeling studies suggest that in the absence of excessive disturbance, A. alba would still

TABLE 3. Filling of potential spatial ranges by four important European tree species according to bioclimatic modeling.

\begin{tabular}{lccc}
\hline \hline \multicolumn{1}{c}{ Species } & $\begin{array}{c}\text { Potential range } \\
\text { filling with TP (\%) }\end{array}$ & $\begin{array}{c}\text { Potential range filling } \\
\text { with TPFSHDW (\%) }\end{array}$ & $\begin{array}{c}\text { Reduction of potential } \\
\text { range with TPFSHDW (\%) }\end{array}$ \\
\hline Abies alba & 12.4 & 25.2 & 51.0 \\
Picea abies & 52.6 & 62.5 & 16.6 \\
Fagus sylvatica & 30.3 & 38.5 & 21.3 \\
Quercus robur & 37.0 & 47.6 & 22.2 \\
\hline
\end{tabular}

Note: Abbreviations are: $\mathrm{T}$, mean monthly and annual temperature; $\mathrm{P}$, mean monthly and annual precipitation; $\mathrm{F}$, ground frost; $\mathrm{S}$, sunshine duration; $\mathrm{H}$, relative humidity; $\mathrm{D}$, mean diurnal temperature; $\mathrm{W}$, wet days. 


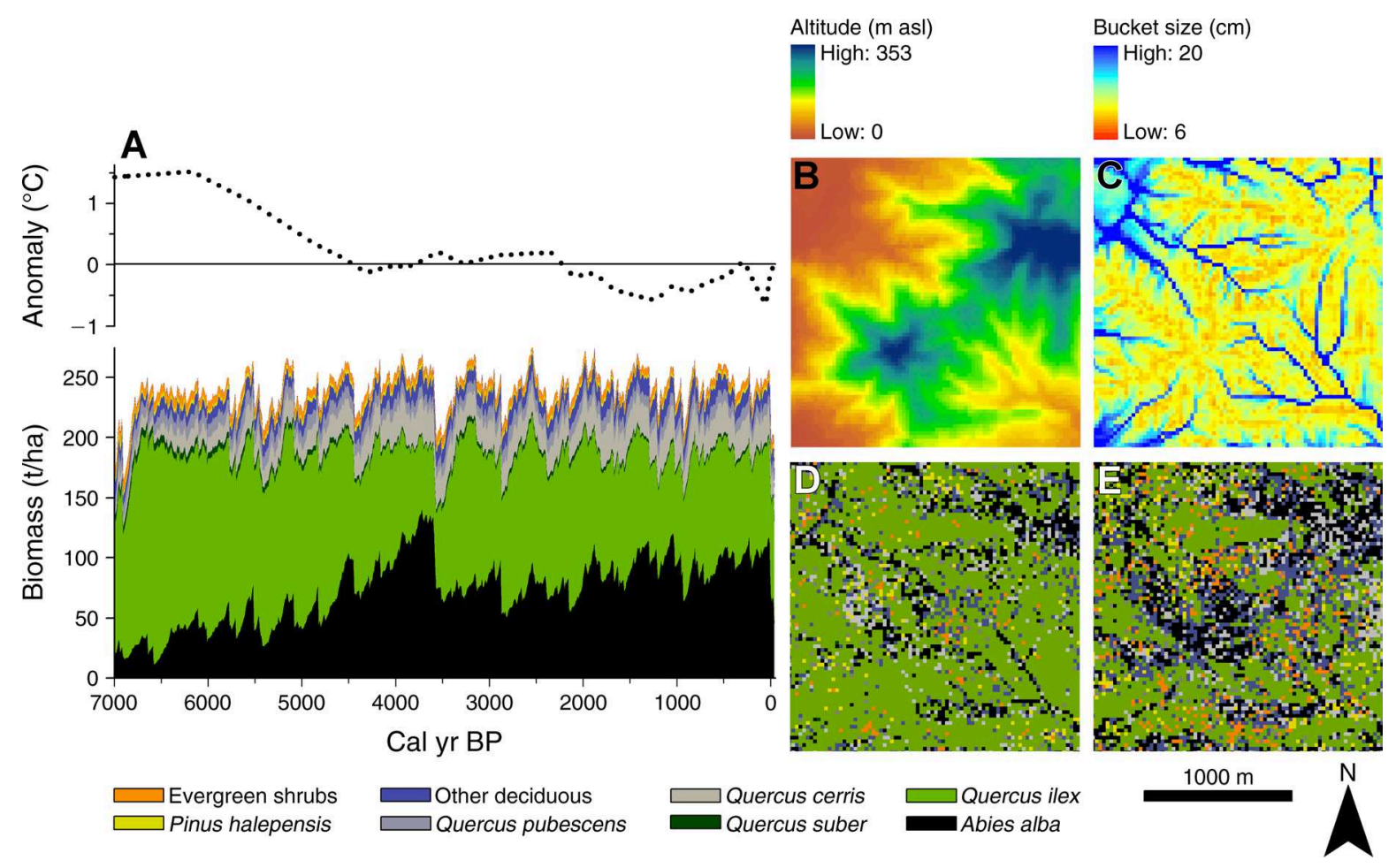

FIg. 9. Vegetation simulated near Lago di Massaciuccoli, Tuscany, with the LandClim dynamic landscape vegetation model using a chironomid-inferred Holocene temperature reconstruction (Samartin 2011) from Lago Verdarolo in the Tuscan-Emilian Apennines, recent precipitation variability, and low disturbance. (A) On the top is the July temperature anomaly from today after $7000 \mathrm{cal}$ yr BP; and on the bottom is the simulated vegetation for the same period. In contrast to pollen data from Lago di Massaciuccoli (Colombaroli et al. 2007), which document the collapse of Abies alba after $6000 \mathrm{cal}$ yr BP, the biomass of the species increases after $6000 \mathrm{cal}$ yr BP when summer temperatures declined (note that units for biomass are in metric tons/hectare; 1 metric ton $(\mathrm{t})=1 \mathrm{Mg}$ ). (B) Altitude and $(\mathrm{C})$ soil bucket size, a measurement of plant-available, soil water-holding capacity, in a representative 4- $\mathrm{km}^{2}$ portion of the simulation landscape. (D, E) Species or groups of species with the most simulated biomass in each model grid cell (D) at $6000 \mathrm{cal} \mathrm{yr} \mathrm{BP}$ and (E) at present. A. alba can dominate only the most mesic settings (e.g., deep soils in valley bottoms) at $6000 \mathrm{cal}$ yr BP but expands on northerly slopes during the late Holocene and has broader potential landscape dominance at present.

form thermophilous mixed forests in the sub-Mediterranean lowland forests of northern Italy and southern Switzerland (Keller et al. 2002, Wick and Möhl 2006). Similarly, our modeling results suggest that $A$. alba has still the potential to co-dominate the vegetation and to form forests on the Mediterranean coast, if precipitation is sufficient $(>600-700 \mathrm{~mm}$ annual precipitation, $>120$ $150 \mathrm{~mm}$ summer precipitation, i.e., total for June, July, and August) and fire and browsing disturbance are not excessive (Henne et al. 2013, Fig. 9). Our modeling outcome is in very good agreement with paleobotanical data from the Mediterranean realm that provide unambiguous evidence of the occurrence of $A$. alba forests before fire and land-use disturbance increased markedly during the Neolithic (Tinner et al. 1999, Gobet et al. 2000, Colombaroli et al. 2007, Colombaroli et al. 2008, Vescovi et al. 2010b).

\section{Climatic conditions before the extinction of Mediterranean Abies alba forests}

Paleoclimatic evidence suggests that summer temperatures were higher than today when $A$. alba formed forests that reached the Mediterranean coastlands in Tuscany. Non-pollen quantitative climatic reconstructions are very scarce in the Mediterranean region. Welldated chironomid-inferred temperature reconstructions (Samartin 2011) from the Tuscan-Emilian Apennines show that Holocene (summer) temperatures were at their maximum between 8000 and 6000 cal BP (Figs. 3 and 9), which is in excellent agreement with quantitative temperature estimates from the Alps $\sim 300 \mathrm{~km}$ northwest of the Mediterranean sites (e.g., Heiri et al. 2003, 2004), which suggest $1-2^{\circ} \mathrm{C}$ warmer-than-present summers during the early and mid-Holocene. Sea surface temperature (SST) reconstructions from the Mediterranean Sea indicate $\sim 1^{\circ} \mathrm{C}$ warmer-than-today conditions during the early and mid-Holocene (Abrantes et al. 2012). This thermal optimum was mainly the result of orbital parameters that caused maximum summer insolation, and thus, increased (summer) temperatures in the northern hemisphere (Kutzbach and Webb 1993, Wanner et al. 2008). Dynamic climatic models are in good agreement with the paleoclimatic evidence and suggest a mid-Holocene thermal maximum at ca. 7000 
cal yr BP over Europe (Renssen et al. 2009). Our climate simulations for 6000 cal BP resolve the seasonal variation at a monthly scale for different areas in the study region (Fig. 4). According to these simulations, summers were $1-2^{\circ} \mathrm{C}$ warmer, from the Alps to southern Italy, while winters were only slightly cooler than today. Adding this paleoclimatic component $\left(1-2^{\circ} \mathrm{C}\right)$, which is in best agreement with the available non-pollen climatic proxies to the difference derived from the past occurrence of Mediterranean A. alba forests $\left(\sim 4-5^{\circ} \mathrm{C}\right)$ leads to an upper mean July temperature limit for silver fir forest growth $\sim 7^{\circ} \mathrm{C}$ warmer than today $\left(24-25^{\circ}\right.$ vs. 18 $\left.19^{\circ} \mathrm{C}\right)$.

Holocene paleo-precipitation reconstructions are even scarcer than quantitative non-pollen paleo-temperature estimates. Lake-level reconstructions from Tuscany suggest that the mid-Holocene (8000-5000 cal BP) was substantially drier than the late Holocene, including present times (Magny et al. 2007). The central Italian lake-level data are in very good agreement with lakelevel evidence from northern Italy (Magny et al. 2009, 2012) and the Jura Mountains north of the Alps (Magny et al. 2011b). The finding suggests a millennial-scale control on Mediterranean and central European lake levels by orbital forcing, leading to lower lake water tables in the mid-Holocene as a consequence of higher summer insolation (Kutzbach and Webb 1993, Magny et al. 2011a). Likewise, lower-than-present summer precipitation in the Alps and Mediterranean Italy is suggested by climatic simulations (Fig. 4), while winters were probably significantly wetter. Such pronounced seasonal differences during the mid-Holocene may explain the opposing moisture signals in oxygen isotopes and lake-level studies in central Italy (Giraudi et al. 2011).

Non-pollen evidence suggests that Holocene temperatures in Europe and Greenland were probably $2-4^{\circ} \mathrm{C}$ lower than during the Eemian interglacial (Aalbersberg and Litt 1998, Novenko et al. 2009, van de Berg et al. 2011, Willis and MacDonald 2011). Precipitation was possibly comparable to the Holocene or slightly higher, though non-pollen evidence is very scarce (Zagwijn 1996, Coope 2000). A. alba was widespread in Europe during the Eemian and its range larger than during the Holocene (Lang 1994). During the late Eemian, A. alba reached pollen abundances comparable to those of the Holocene at our southernmost site Monticchio (ca. 122 000-120 000 yr BP; Table 2; Allen and Huntley 2009). The climatic setting and the thermophilous vegetation composition (e.g., Quercus robur-t., Ulmus, Tilia, Acer, Q. ilex-t., Phillyrea, Pistacia, Olea, Castanea sativa, Ostrya, Hedera helix, Buxus sempervirens) suggest an Eemian occurrence of $A$. alba under meso-Mediterranean conditions, a situation that is comparable to the Holocene before land use intensified during the Neolithic. Interestingly, very much in contrast to the Holocene, A. alba never vanished during the Eemian interglacial. Instead the species expanded to $>20 \%$ during the late Eemian at ca. $118000-114000$ yr BP (Allen and Huntley 2009), when moisture availability probably increased (Tzedakis et al. 2009). This evidence supports our interpretation and our dynamic modeling results for the Mediterranean coast, which show that in the absence of intense land use, A. alba would have persisted and even expanded during the late Holocene (Fig. 9), as was the case during previous interglacials (Tzedakis et al. 2009). When the last glacial began at ca. $110000 \mathrm{BP}$, A. alba declined considerably to $<5 \%$ at Monticchio (Allen and Huntley 2009). Afterwards the tree re-expanded during the following warm interstadial at ca. $98000 \mathrm{cal}$ yr BP (Table 2; Allen et al. 1999). These mixed $A$. alba forests finally collapsed at ca. $85000 \mathrm{yr}$ BP, when climate became colder and the steppe expanded (Allen et al. 1999).

Taken together, we can thus reject the alternative explanation that $A$. alba was more abundant in the midHolocene at the Mediterranean sites because the climate was cooler and/or wetter than today. On the contrary, all non-pollen evidence suggests that climatic conditions were significantly warmer than today, whereas summer precipitation was comparable or even reduced. This conclusion is corroborated by the European Eemian evidence, suggesting a higher importance of $A$. alba under temperatures that were significantly higher than today.

\section{Implications for global-change ecology and mitigation strategies}

Our study shows that the ecology and climatic niche of $A$. alba is not well understood yet. This finding has significant consequences, since it implies that considerable uncertainties exist about potential species responses to anticipated climate change (IPCC 2007). In the upper vegetational belts of the Alps, wide areas previously occupied by A. alba are now colonized by Picea abies or Fagus sylvatica (Tinner and Ammann 2005). Under temperate to warm conditions, these two species are more drought-sensitive and less competitive than A. alba (Ellenberg 2009, Ellenberg and Leuschner 2010, Henne et al. 2011) and may thus collapse in response of future warming and declining moisture availability $(\mathrm{CH} 2011$ 2011).

Filling the knowledge gap about $A$. alba may improve climate change mitigation strategies. The species has the potential to ensure stand and slope stabilities and thus protect traffic and settlement infrastructure in mountainous areas of southern and central Europe under global-warming conditions. Likewise, A. alba may provide the best potential for maintaining high productivity and for protecting carbon stocks in European forests during the next centuries. In particular, European forest owners may use A. alba varieties to replace more drought-sensitive Picea abies and Fagus sylvatica instead of planting non-native species such as Pseudotsuga menziesii (Hanewinkel et al. 2013). Currently, efforts to restore the original natural vegetation are 
being made in European national parks (e.g., Valsecchi et al. 2010, Gallucci and Urbinati 2011). These attempts require the suppression of excessive disturbance agents, such as anthropogenic fires or unnatural herbivore pressure. According to recent observations, A. alba is considerably promoted by the suspension of large-scale wood harvesting (Rovelli 1995, Ott et al. 1997), as well as the reappearance and expansion of predators such as lynx and wolf in the Alps (Baumann et al. 2010), which were certainly regulating ungulate populations before the advent of landscape humanization. The promotion of $A$. alba may also allay the mass expansions of subtropical evergreen exotic species (e.g., Trachycarpus fortunei, Cinnamomum camphora), which are presently colonizing the lowland forests of northern Italy and southern Switzerland together with native evergreen species (e.g., Laurus nobilis, Ilex aquifolium, Quercus ilex, Hedera helix). This expansion started in the 1960s and has been attributed to climate warming (Walther et al. 2002); however, it may also reflect a response to observed declining land use in European mountainous areas, or, in other words, the occupation of an empty ecological niche, which has been created by the demise of the thermophilous evergreen $A$. alba forests in the lowlands of the Italian Peninsula (Carraro et al. 1999, Tinner et al. 1999). Finally, Abies alba is an important keystone species of European ecosystems (Ott et al. 1997). Protecting silver fir against excessive disturbance (e.g., fire, browsing) may significantly contribute to maintaining biodiversity.

Uncertainties persist with regard to the $A$. alba subspecies or populations that may have been erased by anthropogenic pressure during the late Holocene. These populations possibly possessed adaptations and life traits that are not preserved in the extant $A$. alba genome (Liepelt et al. 2009, 2010). The presence of relict $A$. alba trees and stands under warm $\left(22-23^{\circ} \mathrm{C}\right.$ July means) conditions in the Italian Peninsula (Rovelli 1995, Carraro et al. 1999) may mean substantial genetic losses have not occurred. However, a thorough assessment of this issue can only be reached by fossil DNA analyses and accompanying extensive surveys of modern genetic variation (Magyari et al. 2011). Future paleoecological research should therefore be devoted to improve and use (sedimentary) paleo-DNA approaches.

\section{Conclusions}

Our results imply that the future spatial range of $A$. alba may not contract regardless of migration success, even if climate should become markedly warmer than today, with summer temperatures increasing by $5-7^{\circ} \mathrm{C}$, as long as precipitation does not decline significantly (i.e., below 700-800 $\mathrm{mm} / \mathrm{yr}$ ) and anthropogenic disturbance (e.g., fire, browsing) does not become excessive. This assessment of the temperature and precipitation resilience of the species corresponds to the temperature extremes of what is expected for the end of the $21 \mathrm{st}$ century in Europe, where the species is abundant today
(CH2011 2011). This outcome is in apparent conflict with recent climate response studies suggesting a reduction of climate suitability for $A$. alba in response to moderate warming during the next decades (Maiorano et al. 2012). The disagreement between the two projections partly results from the inclusion of prehistorical anthropogenic range reductions in our study. Moreover, while Maiorano et al. (2012) considered paleoecological evidence, they did not pay particular attention to the warm edge of the Abies alba range, as evidenced by the failure of their SDMs to project a high climate suitability under current climate conditions for upland areas in central and southern Italy (>800 asl), where the species is still abundant today (Fig. 1).

Ecologically our outcome implies that the present realized climatic niche of the species (as inferred from observations) is significantly reduced if compared to the past realized climatic niche (as reconstructed by paleoecology and dynamic vegetation models such as LandClim). This signifies that incomplete climatic niche filling may primarily result from plurimillennial-long land use and not only from dispersal limitation (Pearman et al. 2008). Furthermore, our results challenge the basic assumption of bioclimatic modeling (Pearson and Dawson 2003) that land use does not exert a dominant control on plant species and vegetation at regional to continental scales $(>200 \mathrm{~km})$. Thus, taking land use and forestry into account is important to gain realistic climate change response assessments, especially in Europe, where humanization of nature started $>5000$ years ago.

The detection of the high relevance of $A$. alba under significantly warmer-than-present conditions was only possible through the investigation of new paleoecological sites, which are not yet included in paleoecological databases such as the European Pollen Database (EPD). Paleoenvironmental records are still very sparse and temporally poorly resolved if compared to contemporary environmental observational networks (Bradley et al. 2003). Retrieving novel paleoenvironmental data will thus substantially contribute to improve assessments of future biosphere dynamics in response to global change. Only very little is known about the ecology and ecophysiology of the relict southern Abies alba varieties (Pignatti 1982), exploring their ecological potential might be highly promising for forest and biodiversity management strategies under global-warming conditions.

ACKNOWLEDGMents

We thank Brigitta Ammann, Jacques-Louis de Beaulieu, Cristina Bellini, Andreas Grünig, Harald Bugmann, Ché Elkin, Aldo Marchetto, Michel Magny, Giorgio Moretti, Florencia Oberli, Roberta Pini, Colin Prentice, Cesare Ravazzi, Willi Tanner, and Boris Vannière for fruitful discussions, as well as for help in the laboratory and field. This project was financed by the Swiss National Science Foundation (SNF), projects PP00P2-114886 and 200021-134616 to W. Tinner; F. Joos and M. Steinacher acknowledge support by the SNF and by the European Commission through the FP7 projects Past4Future 
(grant number 243908) and CARBOCHANGE (grant number 264879). J. Luterbacher acknowledges support from the EU/ FP7 project ACQWA (NO212250), the DFG Projects PRIME 2 (Precipitation In Past Millennia in Europe: extension back to Roman times), within the Priority Programme INTERDYNAMIK and Historical Climatology of the Middle East Based on Arabic Sources Back to AD 800 (LU 1608/2-1 AOBJ 575150). O. Heiri was supported by the European Research Council (Starting Grant Project 239858). We thank the Canton Ticino and the Regions of Basilicata, Emilia-Romagna, and Tuscany for coring permits. The suggestions of two anonymous reviewers significantly improved our manuscript. This is an Oeschger Centre Work Package III Climate Responses and Risks (OCCR WP III) contribution.

\section{Literature Cited}

Aalbersberg, G., and T. Litt. 1998. Multiproxy climate reconstruction for the Eemian and Early Weichselian. Journal of Quaternary Science 13:367-390.

Abrantes, F., A. Voelker, F. J. Sierro, F. Naughton, T. Rodrigues, I. Cacho, D. Ariztegui, D. Brayshaw, M.-A. Sicre, and L. Batista. 2012. Paleoclimate variability in the Mediterranean region. Pages 1-86 in P. Lionello, editor. The climate of the Mediterranean region: from the past to the future. Elsevier, Amsterdam, The Netherlands.

Alba-Sánchez, F., J. A. Lopez-Saez, B. Benito-de Pando, J. C. Linares, D. Nieto-Lugilde, and L. Lopez-Merino. 2010. Past and present potential distribution of the Iberian Abies species: a phytogeographic approach using fossil pollen data and species distribution models. Diversity and Distributions 16:214-228

Allen, J. R. M., et al. 1999. Rapid environmental changes in southern Europe during the last glacial period. Nature 400:740-743.

Allen, J. R. M., and B. Huntley. 2009. Last Interglacial palaeovegetation, palaeoenvironments and chronology: a new record from Lago Grande di Monticchio, southern Italy. Quaternary Science Reviews 28:1521-1538.

Allen, J. R. M., W. A. Watts, E. McGee, and B. Huntley. 2002. Holocene environmental variability: the record from Lago Grande di Monticchio, Italy. Quaternary International 88:69-80.

Alley, R. B., et al. 2003. Abrupt climate change. Science 299:2005-2010.

Amorosi, A., M. R. Lucchi, V. Rossi, and G. Sarti. 2009. Climate change signature of small-scale parasequences from Lateglacial-Holocene transgressive deposits of the Arno valley fill. Palaeogeography, Palaeoclimatology, Palaeoecology 273:142-152.

Anderson, N. J., H. Bugmann, J. A. Dearing, and M. J. Gaillard. 2006. Linking palaeoenvironmental data and models to understand the past and to predict the future. Trends in Ecology and Evolution 21:696-704.

Aussenac, G. 2002. Ecology and ecophysiology of circumMediterranean firs in the context of climate change. Annals of Forest Science 59:823-832.

Badoux, E. 1983. Ertragstafeln. Tables de production. Tanne/ Sapin. Second edition. Eidgenössische Anstalt für das forstliche Versuchswesen, Birmensdorf, Switzerland.

Baumann, M., P. Brang, T. Burger, R. Eyholzer, S. Herzog, N. Imesch, A. Kupferschmid, D. Rüegg, and A. Wehrli. 2010. Wald und Wild: Grundlagen für die Praxis. Wissenschaftliche und methodische Grundlagen zum integralen Management von Reh, Gämse, Rothirsch und ihrem Lebensraum. BAFU, Bern, Switzerland.

Becker, M., and J. Drapier. 1984. The part of allelopathy in the difficulties of white fir regeneration (Abies alba): I. Phytotoxic properties of aqueous extracts of fir needles. Acta Oecologica: Oecologia Plantarum 5:347-356.

Becker, M., and J. Drapier. 1985. The part of allelopathy in the difficulties of white fir regeneration (Abies alba): II. In-situ study of natural leachates of needles, litter and humus. Acta Oecologica: Oecologia Plantarum 6:31-40.

Bellini, C., M. Mariotti-Lippi, and C. Montanari. 2009. The Holocene landscape history of the NW Italian coasts. Holocene 19:1161-1172.

Berger, A. L. 1978. Long-term variations of daily insolation and Quaternary climatic changes. Journal of the Atmospheric Sciences 35:2362-2367.

Bernetti, G. 1995. Selvicoltura speciale. UTET, Torino, Italy.

Bertolani Marchetti, D., et al. 1984. Recherches géobotaniques sur les Monts Madonie (Sicile du Nord). Webbia 38:329-348.

Birks, H. J. B., and A. D. Gordon. 1985. Numerical methods in Quaternary pollen analysis. Academic Press, London, UK.

Blunier, T., and E. J. Brook. 2001. Timing of millennial-scale climate change in Antarctica and Greenland during the last glacial period. Science 291:109-112.

Boville, B. A., and P. R. Gent. 1998. The NCAR Climate System Model, version 1. Journal of Climate 11:1115-1130.

Bozbiyik, A., M. Steinacher, F. Joos, T. F. Stocker, and L. Menviel. 2011. Fingerprints of changes in the terrestrial carbon cycle in response to large reorganizations in ocean circulation. Climate of the Past 7:319-338.

Bradley, R. S., K. D. Alverson, and T. F. Pedersen. 2003. Challenges of a changing earth: past perspectives, future concerns. Pages 163-167 in K. D. Alverson, R. S. Bradley, and T. F. Pedersen, editors. Paleoclimate, global change and the future. Springer, Berlin, Germany.

Brooks, S. J. 2006. Fossil midges (Diptera: Chironomidae) as palaeoclimatic indicators for the Eurasian region. Quaternary Science Reviews 25:1894-1910.

Büntgen, U., et al. 2011. 2500 Years of European Climate Variability and Human Susceptibility. Science 331:578-582.

Carraro, G., F. Klötzli, G.-R. Walther, P. Gianoni, and R. Mossi. 1999. Observed changes in vegetation in relation to climate warming. VDF Hochschulverlag AG an der ETH Zürich, Zürich, Switzerland.

CH2011. 2011. Swiss climate change scenarios CH2011. C2SM, MeteoSwiss, ETH, NCCR Climate, and OcCC, Zurich, Switzerland.

Colombaroli, D., A. Marchetto, and W. Tinner. 2007. Longterm interactions between Mediterranean climate, vegetation and fire regime at Lago di Massaciuccoli (Tuscany, Italy). Journal of Ecology 95:755-770.

Colombaroli, D., B. Vanniere, C. Emmanuel, M. Magny, and W. Tinner. 2008. Fire-vegetation interactions during the Mesolithic-Neolithic transition at Lago dell'Accesa, Tuscany, Italy. Holocene 18:679-692.

Coope, G. R. 2000. The climatic significance of coleopteran assemblages from the Eemian deposits in southern England. Netherlands Journal of Geosciences 79:257-267.

Cortini Pedrotti, C. 1967. L'abetina di Varramista (Pisa). Flora fanerogamica e briologica e caratteristiche geobotaniche. Webbia 22:39-65.

Cremer, E., B. Ziegenhagen, K. Schulerowitz, C. Mengel, K. Donges, R. Bialozyt, E. Hussendorfer, and S. Liepelt. 2012. Local seed dispersal in European silver fir (Abies alba Mill.): lessons learned from a seed trap experiment. TreesStructure and Function 26:987-996.

Davis, B. A. S., S. Brewer, A. C. Stevenson, and J. Guiot. 2003. The temperature of Europe during the Holocene reconstructed from pollen data. Quaternary Science Reviews 22:17011716.

Desiato, F., F. Lena, and A. Toreti. 2007. SCIA: a system for a better knowledge of the Italian climate. Bollettino di Geofisica Teorica ed Applicata 48:351-358.

Doney, S. C., K. Lindsay, I. Fung, and J. John. 2006. Natural variability in a stable, 1000-yr global coupled climate-carbon cycle simulation. Journal of Climate 19:3033-3054.

Drescher-Schneider, R., J. L. de Beaulieu, M. Magny, A. V. Walter-Simonnet, G. Bossuet, L. Millet, E. Brugiapaglia, and A. Drescher. 2007. Vegetation history, climate and human 
impact over the last 15,000 years at Lago dell'Accesa (Tuscany, Central Italy). Vegetation History and Archaeobotany 16:279-299.

Ducrey, M. 1999. Aspetti ecoficiologici della risposta all'adattamento agli estremi climatici degli abeti mediterranei. Linea Ecologica 4:3-12.

Elkin, C., B. Reineking, C. Bigler, and H. Bugmann. 2012. Do small-grain processes matter for landscape scale questions? Sensitivity of a forest landscape model to the formulation of tree growth rate. Landscape Ecology 27:697-711.

Ellenberg, H. 2009. Vegetation ecology of Central Europe. Fourth edition. Cambridge University Press, Cambridge, UK.

Ellenberg, H., and C. Leuschner. 2010. Vegetation Mitteleuropas mit den Alpen. Ulmer, Stuttgart, Germany.

EUFORGEN. 2012. European forest genetic resources programme. Bioversity International, Maccarese Rome, Italy.

Frey, W., and R. Lösch. 2010. Geobotanik. Spektrum, Heidelberg, Germany.

Gallucci, V., and C. Urbinati. 2011. Abete bianco nelle faggete dei Monti di Laga. Quattro secoli di storia degli anelli legnosi. Sherwood 174:13-16.

Giraudi, C., M. Magny, G. Zanchetta, and R. N. Drysdale. 2011. The Holocene climatic evolution of Mediterranean Italy: A review of the continental geological data. Holocene 21:105-115.

Gobet, E., W. Tinner, P. Hubschmid, I. Jansen, M. Wehrli, B. Ammann, and L. Wick. 2000. Influence of human impact and bedrock differences on the vegetational history of the Insubrian Southern Alps. Vegetation History and Archaeobotany 9:175-178.

Hanewinkel, M., D. A. Cullman, M.-J. Schelhaas, G.-J. Nabuurs, and N. E. Zimmermann. 2013. Climate change may cause severe loss in the economic value of European forest land. Nature Climatic Change 3:203-207.

Heiri, O., S. J. Brooks, H. J. B. Birks, and A. F. Lotter. 2011. A 274-lake calibration data-set and interference model for chironomid-based summer air temperature reconstruction in Europe. Quaternary Science Reviews 30:3445-3456.

Heiri, O., and A. F. Lotter. 2001. Effect of low count sums on quantitative environmental reconstructions: an example using subfossil chironomids. Journal of Paleolimnology 26:343-350.

Heiri, O., A. F. Lotter, S. Hausmann, and F. Kienast. 2003. A chironomid-based Holocene summer air temperature reconstruction from the Swiss Alps. The Holocene 13:477-484.

Heiri, O., W. Tinner, and A. F. Lotter. 2004. Evidence for cooler European summers during periods of changing meltwater flux to the North Atlantic. Proceedings of the National Academy of Sciences USA 101:15285-15288.

Henne, P. D., C. M. Elkin, D. Colombaroli, S. Samartin, H. Bugmann, O. Heiri, and W. Tinner. 2013. Impacts of changing climate and land use on vegetation dynamics in a Mediterranean ecosystem: Insights from paleoecology and dynamic modeling. Landscape Ecology. 10.1007/s10980-0129782-8

Henne, P. D., C. M. Elkin, B. Reineking, H. Bugmann, and W. Tinner. 2011. Did soil development limit spruce (Picea abies) expansion in the Central Alps during the Holocene? Testing a palaeobotanical hypothesis with a dynamic landscape model. Journal of Biogeography 38:933-949.

IPCC. 2007. IPCC fourth assessment report. Contributions of Working Groups I and II to the Fourth Assessment Report of the Intergovernmental Panel on Climate Change. Cambridge University Press, Cambridge, UK.

Jackson, S. T., and R. J. Hobbs. 2009. Ecological restoration in the light of ecological history. Science 325:567-569.

Kaltenrieder, P., C. A. Belis, S. Hofstetter, B. Ammann, C. Ravazzi, and W. Tinner. 2009. Environmental and climatic conditions at a potential Glacial refugial site of tree species near the Southern Alpine glaciers. New insights from multiproxy sedimentary studies at Lago della Costa (Euganean Hills, Northeastern Italy). Quaternary Science Reviews 28:2647-2662.

Keller, F., H. Lischke, T. Mathis, A. Mohl, L. Wick, B. Ammann, and F. Kienast. 2002. Effects of climate, fire, and humans on forest dynamics: forest simulations compared to the palaeoecological record. Ecological Modelling 152:109 127.

Kozakova, R., P. Samonil, P. Kunes, J. Novak, P. Kocar, and R. Kocarova. 2011. Contrasting local and regional Holocene histories of Abies alba in the Czech Republic in relation to human impact: Evidence from forestry, pollen and anthracological data. Holocene 21:431-444.

Kutzbach, J. E., and T. Webb III. 1993. Conceptual basis for understanding late-Quaternary climates. Pages 5-11 in H. E. Wright, Jr., J. E. Kutzbach, T. Webb III, W. F. Ruddiman, F. A. Street-Perrott, and P. J. Bartlein, editors. Global climates since the last Glacial maximum. University of Minnesota Press, Minneapolis, Minnesota, USA.

Lang, G. 1992. Some aspects of European late- and post-glacial flora history. Acta Botanica Fennica 144:1-17.

Lang, G. 1994. Quartäre Vegetationsgeschichte Europas. Methoden und Ergebnisse. G. Fischer, Jena, Germany.

Lauber, K., and G. Wagner. 1996. Flora Helvetica. Haupt, Bern, Switzerland.

Liepelt, S., et al. 2009. Postglacial range expansion and its genetic imprints in Abies alba (Mill.): A synthesis from palaeobotanic and genetic data. Review of Palaeobotany and Palynology 153:139-149.

Liepelt, S., E. Mayland-Quellhorst, M. Lahme, and B. Ziegenhagen. 2010. Contrasting geographical patterns of ancient and modern genetic lineages in Mediterranean Abies species. Plant Systematics and Evolution 284:141-151.

Lingg, W. A. 1986. Ökologie der inneralpinen Weisstannenvorkommen (Abies alba Mill.) im Wallis $(\mathrm{CH})$. Mitteilungen der Eidgenössischen Forschungsanstalt Wald, Schnee und Landschaft 62:1-466.

Lotter, A. F. 1999. Late-glacial and Holocene vegetation history and dynamics as evidenced by pollen and plant macrofossil analyses in annually laminated sediments from Soppensee (Central Switzerland). Vegetation History and Archaeobotany 8:165-184.

Lowe, J. J., and C. Watson. 1993. Late-Glacial and Early Holocene pollen stratigraphy of the Northern Apennines, Italy. Quaternary Science Reviews 12:727-738.

Magny, M., G. Bossuet, P. Ruffaldi, A. Leroux, and J. Mouthon. 2011a. Orbital imprint on Holocene palaeohydrological variations in west-central Europe as reflected by lakelevel changes at Cerin (Jura Mountains, eastern France). Journal of Quaternary Science 26:171-177.

Magny, M., et al. 2007. Holocene climate changes in the central Mediterranean as recorded by lake-level fluctuations at Lake Accesa (Tuscany, Italy). Quaternary Science Reviews 26:1736-1758.

Magny, M., et al. 2009. Late-Holocene climatic variability south of the Alps as recorded by lake-level fluctuations at Lake Ledro, Trentino, Italy. Holocene 19:575-589.

Magny, M., S. Joannin, D. Galop, B. Vanniere, J. N. Haas, M. Bassetti, P. Bellintani, R. Scandolari, and M. Desmet. 2012. Holocene palaeohydrological changes in the northern Mediterranean borderlands as reflected by the lake-level record of Lake Ledro, northeastern Italy. Quaternary Research 77:382-396.

Magny, M., O. Peyron, E. Gauthier, B. Vanniere, L. Millet, and B. Vermot-Desroches. 2011b. Quantitative estimates of temperature and precipitation changes over the last millennium from pollen and lake-level data at Lake Joux, Swiss Jura Mountains. Quaternary Research 75:45-54.

Magny, M., B. Vanniere, C. Calo, L. Millet, A. Leroux, O. Peyron, G. Zanchetta, T. La Mantia, and W. Tinner. 2011c. Holocene hydrological changes in south-western Mediterra- 
nean as recorded by lake-level fluctuations at Lago Preola, a coastal lake in southern Sicily, Italy. Quaternary Science Reviews 30:2459-2475.

Magyari, E. K., A. Major, M. Balint, J. Nedli, M. Braun, I. Racz, and L. Parducci. 2011. Population dynamics and genetic changes of Picea abies in the South Carpathians revealed by pollen and ancient DNA analyses. BMC Evolutionary Biology 11:66.

Maiorano, L., et al. 2012. Building the niche through time: using 13,000 years of data to predict the effects of climate change on three tree species in Europe. Global Ecology and Biogeography 22:301-317.

Marchetto, A., D. Colombaroli, and W. Tinner. 2008. Diatom response to mid-Holocene climate change in Lago di Massaciuccoli (Tuscany, Italy). Journal of Paleolimnology 40:235-245.

Mariotti-Lippi, M., C. Bellini, C. Trinci, M. Benvenuti, P. Pallecchi, and M. Sagri. 2007. Pollen analysis of the ship site of Pisa San Rossore, Tuscany, Italy: the implications for catastrophic hydrological events and climatic change during the late Holocene. Vegetation History and Archaeobotany $16: 453-465$.

Mayer, H. 1984a. Waldbau auf soziologisch-ökologischer Grundlage. Gustav Fischer Verlag, Stuttgart, Germany.

Mayer, H. 1984b. Wälder Europas. G. Fischer, Stuttgart, Germany.

Moore, P. D., J. A. Webb, and M. E. Collinson. 1991. Pollen analysis. Second edition. Blackwell Scientific Publications, London, UK.

New, M., D. Lister, M. Hulme, and I. Makin. 2000. A highresolution data set of surface climate over global land areas. Climate Research 21:1-25.

New, M., M. Todd, M. Hulme, and P. Jones. 2001. Precipitation measurements and trends in the twentieth century. International Journal of Climatology 21:1899-1922.

Normand, S., R. E. Ricklefs, F. Skov, J. Bladt, O. Tackenberg, and J. C. Svenning. 2011. Postglacial migration supplements climate in determining plant species ranges in Europe. Proceedings of the Royal Society B 278:3644-3653.

Novenko, E., A. Olchev, O. Desherevskaya, and I. Zuganova. 2009. Paleoclimatic reconstructions for the south of Valdai Hills (European Russia) as paleo-analogs of possible regional vegetation changes under global warming. Environmental Research Letters 4:045016.

Ott, E., M. Frehner, H.-U. Frey, and P. Lüscher. 1997. Gebirgsnadelwälder. Ein praxisorientierter Leitfaden für eine standortgerechte Waldbehandlung. Haupt, Bern, Switzerland.

Overpeck, J., C. Whitlock, and B. Huntley. 2003. Terrestrial biosphere dynamics in the climate system: past and future. Pages 81-103 in K. D. Alverson, R. S. Bradley, and T. F. Pedersen, editors. Paleoclimate, global change and the future. Springer, Berlin, Germany.

Pearman, P. B., C. F. Randin, O. Broennimann, P. Vittoz, W. O. van der Knaap, R. Engler, G. Le Lay, N. E. Zimmermann, and A. Guisan. 2008. Prediction of plant species distributions across six millennia. Ecology Letters 11:357-369.

Pearson, R. G., and T. P. Dawson. 2003. Predicting the impacts of climate change on the distribution of species: are bioclimate envelope models useful? Global Ecology and Biogeography 12:361-371.

Pedersen, T. F., R. François, L. François, K. Alverson, and J. McManus. 2003. The Late Quaternary history of biogeochemical cycling of carbon. Pages 63-79 in K. D. Alverson, R. S. Bradley, and T. F. Pedersen, editors. Paleoclimate, global change and the future. Springer, Berlin, Germany.

Pignatti, S. 1982. Flora d'Italia. First edition. Edagricole, Bologna, Italy.

Pignatti, S. 1997. Ecologia del paesaggio. UTET, Unione Tipografico-Editrice Torinese, Torino, Italy.
Pignatti, S. 2005. Valori di bioindicazione delle piante vascolari della flora d'Italia. Braun-Blanquetia 39:3-97.

Power, M. J., et al. 2008. Changes in fire regimes since the Last Glacial Maximum: an assessment based on a global synthesis and analysis of charcoal data. Climate Dynamics 30:887-907.

Prentice, I. C., W. Cramer, S. P. Harrison, R. Leemans, R. A. Monserud, and A. M. Solomon. 1992. A global biome model based on plant physiology and dominance, soil properties and climate. Journal of Biogeography 19:117-134.

Pyne, S. J. 1997. Vestal fire: an environmental history, told through fire, of Europe and Europe's encounter with the world. University of Washington Press, Seattle, Washington, USA.

Raynaud, D., T. Blunier, Y. Ono, and R. J. Delmas. 2003. The Late Quaternary history of atmospheric trace gases and aerosols: interactions between climate and biogeochemical cycles. Pages 13-31 in K. D. Alverson, R. S. Bradley, and T. F. Pedersen, editors. Paleoclimate, global change and the future. Springer, Berlin, Germany.

Renssen, H., H. Seppa, O. Heiri, D. M. Roche, H. Goosse, and T. Fichefet. 2009. The spatial and temporal complexity of the Holocene thermal maximum. Nature Geoscience 2:410-413.

Rovelli, E. 1995. La distribuzione dell'abete (Abies alba Mill.) sull'Appennino. Monti e Boschi 6:5-13.

Sagnard, F., C. Pichot, P. Dreyfus, P. Jordano, and B. Fady. 2007. Modelling seed dispersal to predict seedling recruitment: Recolonization dynamics in a plantation forest. Ecological Modelling 203:464-474.

Samartin, S. 2011. Chironomid-based environmental and climatic reconstructions for the past 30000 years from the northern Italian Peninsula. Dissertation. University of Bern, Bern, Switzerland.

Samartin, S., O. Heiri, E. Vescovi, S. J. Brooks, and W. Tinner. 2012. Lateglacial and early Holocene summer temperatures in the southern Swiss Alps reconstructed using fossil chironomids. Journal of Quaternary Science 27:279-289.

Schneider, R., and K. Tobolski. 1985. Lago di Ganna: LateGlacial and Holocene environments of a lake in the Southern Alps. Dissertationes Botanicae 87:229-271.

Schumacher, S., and H. Bugmann. 2006. The relative importance of climatic effects, wildfires and management for future forest landscape dynamics in the Swiss Alps. Global Change Biology 12:1435-1450.

Schumacher, S., H. Bugmann, and D. J. Mladenoff. 2004. Improving the formulation of tree growth and succession in a spatially explicit landscape model. Ecological Modelling 180:175-194.

Schumacher, S., B. Reineking, J. Sibold, and H. Bugmann. 2006. Modeling the impact of climate and vegetation on fire regimes in mountain landscapes. Landscape Ecology 21:539 554.

Schütt, P., H. Weisgerber, H. J. Schuck, U. Lang, B. Stimm, and A. Roloff. 2004. Lexikon der Nadelbäume. Nikol, Hamburg, Germany.

Simberloff, D. 1998. Flagships, umbrellas, and keystones: Is single-species management passe in the landscape era? Biological Conservation 83:247-257.

Smilauer, P. 1994. Exploratory analysis of palaeoecological data using the program CanoDraw. Journal of Paleolimnology $12: 163-169$.

Soepboer, W., S. Sugita, A. F. Lotter, J. F. N. van Leeuwen, and W. O. van der Knaap. 2007. Pollen productivity estimates for quantitative reconstruction of vegetation cover on the Swiss Plateau. Holocene 17:65-77.

Svenning, J. C., and F. Skov. 2004. Limited filling of the potential range in European tree species. Ecology Letters 7:565-573.

Sykes, M. T., I. C. Prentice, and W. Cramer. 1996. A bioclimatic model for the potential distributions of north European tree species under present and future climates. Journal of Biogeography 23:203-233. 
Szymura, T. H., A. Dunajski, I. Aman, M. Makowski, and M. Szymura. 2007. The spatial pattern and microsites requirements of Abies alba natural regeneration in the Karkonosze Mountains. Dendrobiology 58:51-57.

ter Braak, C. J. F., and S. Juggins. 1993. Weighted averaging partial least-squares regression (Wa-Pls): an improved method for reconstructing environmental variables from species assemblages. Hydrobiologia 269:485-502.

ter Braak, C. J. F., and I. C. Prentice. 1988. A theory of gradient analysis. Advances in Ecological Research 18:271317.

Tinner, W., and B. Ammann. 2005. Long-term responses of mountain ecosystems to environmental changes: Resilience, adjustment, and vulnerability. Pages 133-144 in U. M. Huber, H. Bugmann, and M. Reasoner, editors. Global change and mountain research: state of knowledge overview. Springer, Dordrecht, The Netherlands.

Tinner, W., M. Conedera, E. Gobet, P. Hubschmid, M. Wehrli, and B. Ammann. 2000. A palaeoecological attempt to classify fire sensitivity of trees in the southern Alps. Holocene 10:565574.

Tinner, W., P. Hubschmid, M. Wehrli, B. Ammann, and M. Conedera. 1999. Long-term forest fire ecology and dynamics in southern Switzerland. Journal of Ecology 87:273-289.

Tinner, W., and A. F. Lotter. 2001. Central European vegetation response to abrupt climate change at $8.2 \mathrm{ka}$. Geology 29:551-554.

Tinner, W., and A. F. Lotter. 2006. Holocene expansions of Fagus silvatica and Abies alba in Central Europe: where are we after eight decades of debate? Quaternary Science Reviews 25:526-549.

Tinner, W., E. H. Nielsen, and A. F. Lotter. 2007. Mesolithic agriculture in Switzerland? A critical review of the evidence. Quaternary Science Reviews 26:1416-1431.

Tzedakis, P. C., H. Palike, K. H. Roucoux, and L. de Abreu. 2009. Atmospheric methane, southern European vegetation and low-mid latitude links on orbital and millennial timescales. Earth and Planetary Science Letters 277:307-317.

Valsecchi, V., G. Carraro, M. Conedera, and W. Tinner. 2010. Late-Holocene vegetation and land-use dynamics in the Southern Alps (Switzerland) as a basis for nature protection and forest management. Holocene 20:483-495.

Valsecchi, V., and W. Tinner. 2010. Vegetation responses to climatic variability in the Swiss Southern Alps during the Misox event at the early-mid Holocene transition. Journal of Quaternary Science 25:1248-1258.

van de Berg, W. J., M. van den Broeke, J. Ettema, E. van Meijgaard, and F. Kaspar. 2011. Significant contribution of Nature Geoscience 4:679-683. insolation to Eemian melting of the Greenland ice sheet.

van Leeuwen, J. F. N., C. A. Froyd, W. O. van der Knaap, E. E. Coffey, A. Tye, and K. J. Willis. 2008. Fossil pollen as a guide to conservation in the Galapagos. Science 322:1206.

Vescovi, E., B. Ammann, C. Ravazzi, and W. Tinner. 2010a. A new Late-glacial and Holocene record of vegetation and fire history from Lago del Greppo, northern Apennines, Italy. Vegetation History and Archaeobotany 19:219-233.

Vescovi, E., P. Kaltenrieder, and W. Tinner. 2010b. LateGlacial and Holocene vegetation history of Pavullo nel Frignano (Northern Apennines, Italy). Review of Palaeobotany and Palynology 160:32-45.

Walther, G. R., E. Post, P. Convey, A. Menzel, C. Parmesan, T. J. C. Beebee, J. M. Fromentin, O. Hoegh-Guldberg, and F. Bairlein. 2002. Ecological responses to recent climate change. Nature 416:389-395.

Wanner, H., et al. 2008. Mid- to Late Holocene climate change: an overview. Quaternary Science Reviews 27:1791-1828.

Whitlock, C., S. L. Shafer, and J. Marlon. 2003. The role of climate and vegetation change in shaping past and future fire regimes in the northwestern US and the implications for ecosystem management. Forest Ecology and Management 178:5-21.

Wick, L., and A. Möhl. 2006. The mid-Holocene extinction of silver fir (Abies alba) in the Southern Alps: a consequence of forest fires? Palaeobotanical records and forest simulations. Vegetation History and Archaeobotany 15:435-444.

Wick, L., J. F. N. van Leeuwen, W. O. van der Knaap, and A. F. Lotter. 2003. Holocene vegetation development in the catchment of Sagistalsee (1935 m asl), a small lake in the Swiss Alps. Journal of Paleolimnology 30:261-272.

Willis, K. J., M. B. Araujo, K. D. Bennett, B. Figueroa-Rangel, C. A. Froyd, and N. Myers. 2007. How can a knowledge of the past help to conserve the future? Biodiversity conservation and the relevance of long-term ecological studies. Philosophical Transactions of the Royal Society B 362:175186.

Willis, K. J., and H. J. B. Birks. 2006. What is natural? The need for a long-term perspective in biodiversity conservation. Science 314:1261-1265.

Willis, K. J., and G. M. MacDonald. 2011. Long-term ecological records and their relevance to climate change predictions for a warmer world. Annual Review of Ecology, Evolution, and Systematics 42:267-287.

Willis, K. J., and J. C. McElwain. 2002. The evolution of plants. Oxford University Press, Oxford, UK.

Zagwijn, W. H. 1996. An analysis of Eemian climate in Western and Central Europe. Quaternary Science Reviews 15:451469.

\section{Supplemental Material}

Data Availability

Data associated with this paper have been deposited in Dryad: http://dx.doi.org/10.5061/dryad.df3sn 